\title{
Viscoelastic Testing and Coagulopathy of Traumatic Brain Injury
}

\author{
Jamie L. Bradbury ${ }^{1}$, Scott G. Thomas ${ }^{2}$, Nikki R. Sorg ${ }^{3}{ }^{\oplus}$, Nicolas Mjaess ${ }^{4}{ }^{\oplus}$, Margaret R. Berquist ${ }^{4}$, \\ Toby J. Brenner ${ }^{4}{ }^{3}$, Jack H. Langford ${ }^{4}$, Mathew K. Marsee ${ }^{5}$, Ashton N. Moody ${ }^{3}$, Connor M. Bunch ${ }^{3, *}{ }^{\circ}$, \\ Sandeep R. Sing ${ }^{3}$, Mahmoud D. Al-Fadhl ${ }^{4}{ }^{\circ}$, Qussai Salamah ${ }^{4}$, Tarek Saleh ${ }^{4}$, Neal B. Patel ${ }^{6,7}$, \\ Kashif A. Shaikh ${ }^{6,7}$, Stephen M. Smith ${ }^{6,7}$, Walter S. Langheinrich ${ }^{6,7}$, Daniel H. Fulkerson ${ }^{6,7}$ and Sherry Sixta ${ }^{8}$
}

Citation: Bradbury, J.L.; Thomas, S.G.; Sorg, N.R.; Mjaess, N.; Berquist, M.R.; Brenner, T.J.; Langford, J.H.; Marsee, M.K.; Moody, A.N.; Bunch, C.M.; et al. Viscoelastic Testing and Coagulopathy of Traumatic Brain Injury. J. Clin. Med. 2021, 10, 5039. https://doi.org/10.3390/ jcm10215039

Academic Editors: Mark M. Walsh, Mirjam Bachler and Giancarlo Castaman

Received: 30 September 2021 Accepted: 27 October 2021 Published: 28 October 2021

Publisher's Note: MDPI stays neutral with regard to jurisdictional claims in published maps and institutional affiliations.

Copyright: (c) 2021 by the authors. Licensee MDPI, Basel, Switzerland. This article is an open access article distributed under the terms and conditions of the Creative Commons Attribution (CC BY) license (https:/ / creativecommons.org/licenses/by/ $4.0 /)$.
1 Department of Neurosurgery, Indiana University School of Medicine, Indianapolis, IN 46202, USA; jlbradbu@iupui.edu

2 Department of Trauma Surgery, Memorial Hospital, South Bend, IN 46601, USA; SThomas@beaconhealthsystem.org

3 Department of Emergency Medicine, Indiana University School of Medicine-South Bend, South Bend, IN 46617, USA; nikrsorg@iu.edu (N.R.S.); ashmoody@iu.edu (A.N.M.); singh64@iu.edu (S.R.S.)

4 Department of Intensive Care Medicine, St. Joseph Regional Medical Center, Mishawaka, IN 46545, USA; nmjaess@nd.edu (N.M.); mberquis@nd.edu (M.R.B.); toby.brenner@myemail.indwes.edu (T.J.B.); jlangford@butler.edu (J.H.L.); malfadhl@iu.edu (M.D.A.-F.); kacysalama@yahoo.com (Q.S.); Drsaleh20@gmail.com (T.S.)

5 Department of Otolaryngology, Portsmouth Naval Medical Center, Portsmouth, VA 23708, USA; mkmarsee@gmail.com

6 Department of Neurosurgery, Memorial Hospital, South Bend, IN 46601, USA; npatel@beaconhealthsystem.org (N.B.P.); kshaikh@beaconhealthsystem.org (K.A.S.); SSMITH5@beaconhealthsystem.org (S.M.S.); WLangheinrich@beaconhealthsystem.org (W.S.L.); dhfulkerson@beaconhealthsystem.org (D.H.F.)

7 Department of Neurosurgery, St. Joseph Regional Medical Center, Mishawaka, IN 46545, USA

8 Department of Trauma Surgery, Envision Physician Services, Plano, TX 75093, USA; sherry.sixta@envisionhealth.com

* Correspondence: cmbunch@iu.edu

Abstract: A unique coagulopathy often manifests following traumatic brain injury, leading the clinician down a difficult decision path on appropriate prophylaxis and therapy. Conventional coagulation assays—such as prothrombin time, partial thromboplastin time, and international normalized ratio-have historically been utilized to assess hemostasis and guide treatment following traumatic brain injury. However, these plasma-based assays alone often lack the sensitivity to diagnose and adequately treat coagulopathy associated with traumatic brain injury. Here, we review the whole blood coagulation assays termed viscoelastic tests and their use in traumatic brain injury. Modified viscoelastic tests with platelet function assays have helped elucidate the underlying pathophysiology and guide clinical decisions in a goal-directed fashion. Platelet dysfunction appears to underlie most coagulopathies in this patient population, particularly at the adenosine diphosphate and/or arachidonic acid receptors. Future research will focus not only on the utility of viscoelastic tests in diagnosing coagulopathy in traumatic brain injury, but also on better defining the use of these tests as evidence-based and/or precision-based tools to improve patient outcomes.

Keywords: adenosine diphosphate; arachidonic acid; blood platelets; brain injuries; traumatic; cerebral hemorrhage; critical care; fibrinolysis; mortality; resuscitation; thromboelastography

\section{Introduction}

\subsection{Incidence of Coagulopathy of Traumatic Brain Injury}

Occult coagulopathy of traumatic brain injury (TBI) reportedly affects a high percent of trauma patients with a significant increase in morbidity [1-6]. Literature frequently cites an estimate that "one-third" of patients with a TBI will develop a coagulopathy of TBI (CTBI). However, the true incidence of coagulopathy reported in these patients has been 
cited as anywhere from 7 to $63 \%$. This variability arises from the lack of consistency in the definition of coagulopathy and its causes in TBI. Thus, comparisons of diagnosis and treatment among different populations of CTBI patients remain problematic [6-41].

\subsection{Implications of CTBI and Relation to VET-Based Definition}

In addition to its fluctuant frequency, CTBI is defined by variable cut-off values when using common coagulation assays (CCAs), such as platelet count, prothrombin time (PT), international normalized ratio (INR), partial thromboplastin time (PTT), and fibrinogen levels. CCAs are also limited to detecting the initiation of clot formation and fail to provide information regarding the strength and integrity of the clot formed $[4,6,23,42-48]$. Furthermore, CCAs are not sensitive detectors of hemostatic integrity in patients with multiple systemic polytrauma, including TBI, and fail to predict coagulopathy in patients on pre-injury anticoagulant medications, particularly antiplatelet drugs. Prescriptions for anticoagulants are only continuing to rise due to the increased prevalence of cardiovascular disease and an overall aging population [23,49]. Moreover, patients experience up to a 30fold increased risk of disability and morbidity when compared to TBI patients without the development of coagulopathy [31,50-57]. These facts emphasize the need for a quick and accurate test to identify an abnormal coagulation profile and provide rapid management of coagulopathy if indicated [40].

On the other hand, whole blood hemostatic assays known as viscoelastic tests (VET)s give a more detailed and rapid view of hemostatic integrity by providing a point of care (POC) view of the lifespan of a clot. Published in 2019, the 5th edition of the European guideline on management of major bleeding and coagulopathy following trauma changed their recommendations to include the use of VETs such as thromboelastography $\left(\mathrm{TEG}^{\circledR}\right)$ and rotational thromboelastometry $\left(\mathrm{ROTEM}^{\circledR}\right)$ for patients with systematic multiple trauma and with TBI [47]. There are many advantages in using VETs to detect CTBI $[4,6,23,48,58]$. For example, VETs provide real-time coagulation information on the presence of anticoagulation or antiplatelet medications and the patient's initial coagulation profile, allowing for the monitoring of therapeutic interventions such as hemostatic adjuncts or blood component transfusion $[23,47,58-63]$. Furthermore, modified TEG ${ }^{\circledR}$ Platelet Mapping $\left(\right.$ TEG-PM $\left.^{\circledR}\right)$ and ROTEM $^{\circledR}$ with adjunctive multiple electrode aggregometry (MEA) can also be used to quickly determine platelet function abnormalities from inherent TBI coagulopathy or antiplatelet medications $[23,39,58,61-67]$.

\subsection{Inadequacy of Conventional Coagulation Assays in the Diagnosis of CTBI}

CCAs have historically been the cornerstone of CTBI diagnosis, and this holds true even as recently as a review from late 2020, citing the use of CCAs because of a paucity in literature regarding VET use in CTBI [50]. Yet, CCAs lack of sensitivity in determining hemostatic derangement may contribute to under-diagnosis of coagulopathy in trauma patients $[41,68]$.

Because of their "global" nature, VETs such as ROTEM ${ }^{\circledR}$, TEG $^{\circledR}$, and thrombin generation tests may provide more detailed and useful data concerning the overall ability to achieve hemostasis [6]. These global hemostatic assays use a surrogate endpoint of maximum clot firmness and allow the evaluation of additional information on clotting kinetics, platelet-fibrin interactions, and fibrinolysis [69]. In addition, POC non-VET platelet function tests like Platelet Function Analyzer-100 (PFA-100), MEA (also known as Multiplate ${ }^{\circledR}$ ), VerifyNow P2Y12, and the modified VET TEG-PM ${ }^{\circledR}$ may assist in detecting platelet dysfunction $[39,58,63,64,67,70-74]$. The degree of ADP-receptor inhibition has been suggested to correlate with the severity of TBI, described as a "dose-response relationship" between TBI severity and the degree of platelet dysfunction [64]. There may also be a role for platelet function assays in monitoring platelet dysfunction mediated by antiplatelet agents $[23,52,58,61,64,66,67,74]$.

In both isolated TBI and polytrauma TBI patients, VET assays provide real-time assessment of hemostasis and prognostication $[6,44-47,60,75,76]$. Compared to CCAs, the 
rapidity at which "global" hemostatic assays predict outcome and severity in a population of patients with severe TBI is significant $[6,77]$. Because of these more timely and accurate results, VETs offer additional opportunities to correct hemo-coagulative defects and, ultimately, improve patient outcomes. With these capabilities, VETs like ROTEM ${ }^{\circledR}$ and TEG ${ }^{\circledR}$ are gaining acceptance in clinical practice and represent a mechanism to improve patient care $[23,47,78-80]$.

VET analysis of the coagulopathic spectrum of CTBI reflects the pathophysiology of that spectrum whether associated with isolated TBI or with TBI complicated by traumainduced coagulopathy $[23,47,48,60-62,81]$.

\section{Pathophysiology in CTBI and Its Relation to VETs}

CTBI is associated with a disorder of primary hemostasis, requiring early utilization of platelet function testing to define the coagulopathy. The progression of platelet dysfunction can be monitored by VETs [23,48,53,56,60,82].

After the initial TBI, platelet receptors demonstrate early inhibition, and the degree to which this occurs is a function of the TBI severity; mortality is irrespective of total platelet count. This inhibited platelet phenotype is indicated by a malfunction in platelet receptors for adenosine diphosphate (ADP) or arachidonic acid (AA) [1,53,83-86] as well as other platelet receptors such as collagen, ristocetin, Thrombin receptor activating peptides (TRAP), and protease activated receptor-1 (PAR-1) in TBI [39,65,87].

$\mathrm{Xu}$ et al. suggested TBI elicits two distinct processes that may cause coagulopathy: local primary hemostasis to the injured site and systemic endotheliopathy in part attributable to relatively high levels of von Willebrand factor (vWF) stored in brain tissue [88]. First, the vWFs are immobilized at the injured site causing rapid local platelet activation to seal off the vascular injury. Second, the damage in the blood-brain barrier (BBB) causes injured brain cells to release extracellular vesicles comprising procoagulant molecules, notably brain tissue factor (TF) (which is usually isolated from blood), which then further activates the remote endothelial cells and platelets systemically to release more stored uncleaved vWF and exacerbating systemic pro-coagulation [88,89].

The endothelial dysfunction of CTBI then results in a crosstalk between dysfunctional platelets and endothelium. This is the earliest manifestation of CTBI, first demonstrated by VETs, which quantify dysfunction of varying platelet receptors. This CTBI pathophysiology often results in hemorrhagic expansion. Therefore, the pathophysiology of CTBI can be more effectively assayed by VETs with specialized function analysis than by CCAs, as has been shown for multiple systemic trauma [23,29,38,68,83,84,90-98]. Because of this early platelet hyperactivation and subsequent hypercoagulation, the consumption and/or exhaustion of platelets and coagulation factors leads to a decrease in fibrinogen, often resulting in the later onset of bleeding [23,52,53,99,100].

In addition, a significant number of patients with CTBI have suppressed fibrinolysis, termed 'fibrinolytic shutdown'. True hyperfibrinolysis as manifested by VETs is uncommon and has been supported by the recent failure of studies to confirm the findings of the CRASH-3 trial, demonstrating a small therapeutic benefit of the antifibrinolytic tranexamic acid. It has been proposed that VETs are not sensitive enough to determine occult fibrinolysis. There may be intracerebral fibrinolysis not detected by in vitro measurement of whole blood VET samples [95,101-104].

\section{Basics of TEG $^{\circledR} /$ ROTEM $^{\circledR}$}

\subsection{Description of the Cup and Pin}

$\mathrm{TEG}^{\circledR}$ and $\mathrm{ROTEM}^{\circledR}$ tracings depict hemostatic integrity, measuring initiation, amplification, propagation, and termination of whole blood to form a clot. Figure 1 demonstrates and describes the pin and cup procedure for carrying out TEG $^{\circledR}$ and ROTEM $^{\circledR}$ testing $[43,105-108]$. TEG ${ }^{\circledR}$ and ROTEM $^{\circledR}$ devices apply a rotation and measure the change in tension on the pin within the cup as the clot forms (Figure 1). This is plotted over time, generating the parameters of TEG ${ }^{\circledR}$ and $\operatorname{ROTEM}^{\circledR}$ (Figure 2) $[43,106,107]$. 


\section{TEG $^{\circledR}$}

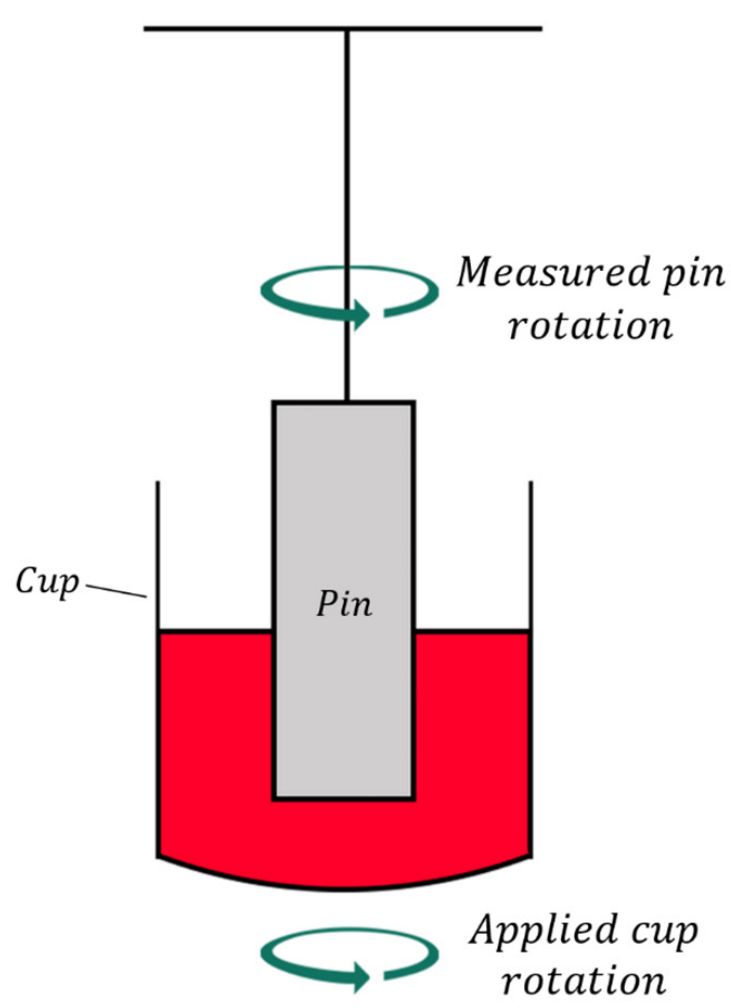

\section{ROTEM $^{\circledR}$}

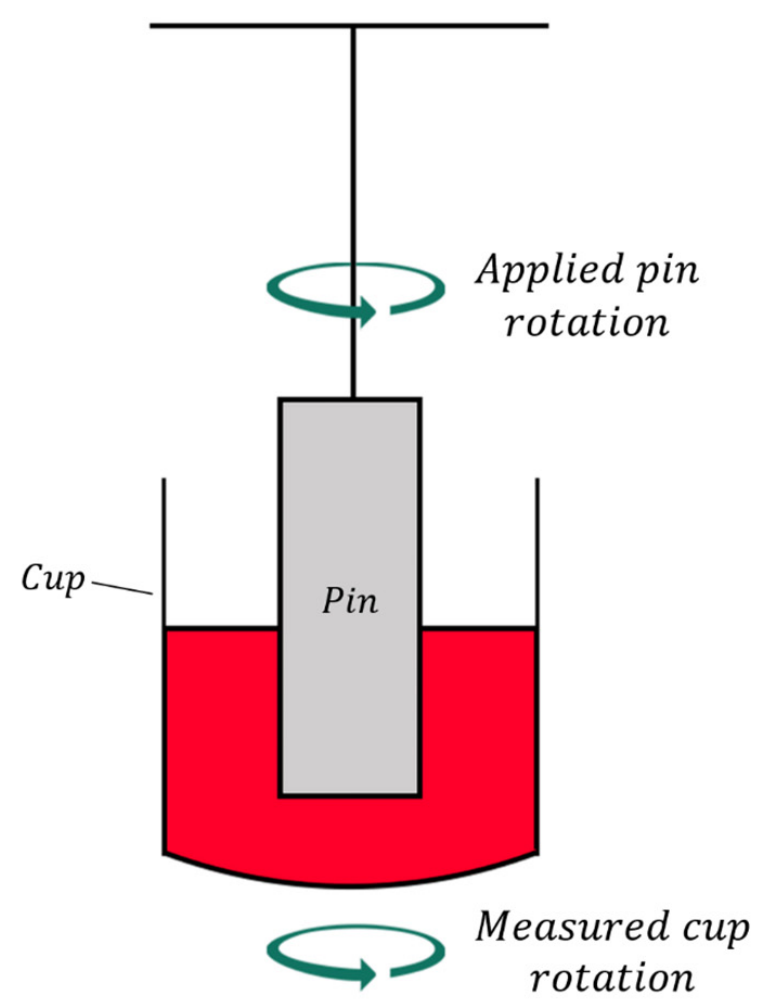

Figure 1. The TEG ${ }^{\circledR}$ and ROTEM ${ }^{\circledR}$ analyzers are each composed of a cup containing a whole blood sample, a pin suspended in the blood sample, a torsion wire, and a transducer. The cup is rotated at a speed of $4.45^{\circ}$ per $10 \mathrm{~s}$ in $\mathrm{TEG}^{\circledR}$. In $\mathrm{ROTEM}^{\circledR}$, the pin is instead rotated, at the same speed of $4.45^{\circ}$ per $10 \mathrm{~s}$. In both assays, clotting of the whole blood gradually synchronizes the rotations of the cup and pin, which causes a change in torque on the torsion wire that is measured by the transducer. Various coagulation activators may be used depending on the assay. Intrinsic coagulation activators include kaolin or ellagic acid; extrinsic activation most commonly uses tissue factor $[43,106,107]$.

3.2. TEG-PM ${ }^{\circledR}$ and ROTEM ${ }^{\circledR}$ with Specialized Platelet Function Testing to Diagnose and Guide Platelet Transfusion in Patients with CTBI

Trauma can induce platelet dysfunction, which may not be detectable by standard ROTEM $^{\circledR}$ or TEG ${ }^{\circledR}$ assays. Platelet function alone can be studied using TEG-PM ${ }^{\circledR}$ using heparin, factor XIII, reptilase, AA, and ADP to form platelet-fibrin clots independent of thrombin as demonstrated in Figure 3 [109]. Figure 4 shows the platelet mapping tracing superimposed on a physiologic $\mathrm{TEG}^{\circledR}$ tracing.

In trauma patients and TBI patients, TEG-PM ${ }^{\circledR}$ AA inhibition is significantly higher than in healthy controls $[1,110]$. In TBI versus non-TBI trauma patients, TEG-PM ${ }^{\circledR}$ AA inhibition is also significantly higher [110]. CCAs and standard TEG ${ }^{\circledR}$ variables (R, $\left.\alpha, M A\right)$ are relatively normal, while TEG-PM ${ }^{\circledR}$ ADP inhibition is significantly higher in patients with isolated TBI versus control subjects. Platelet dysfunction is also significantly higher in patients with severe versus mild-to-moderate TBI $[1,53,63,64]$. 


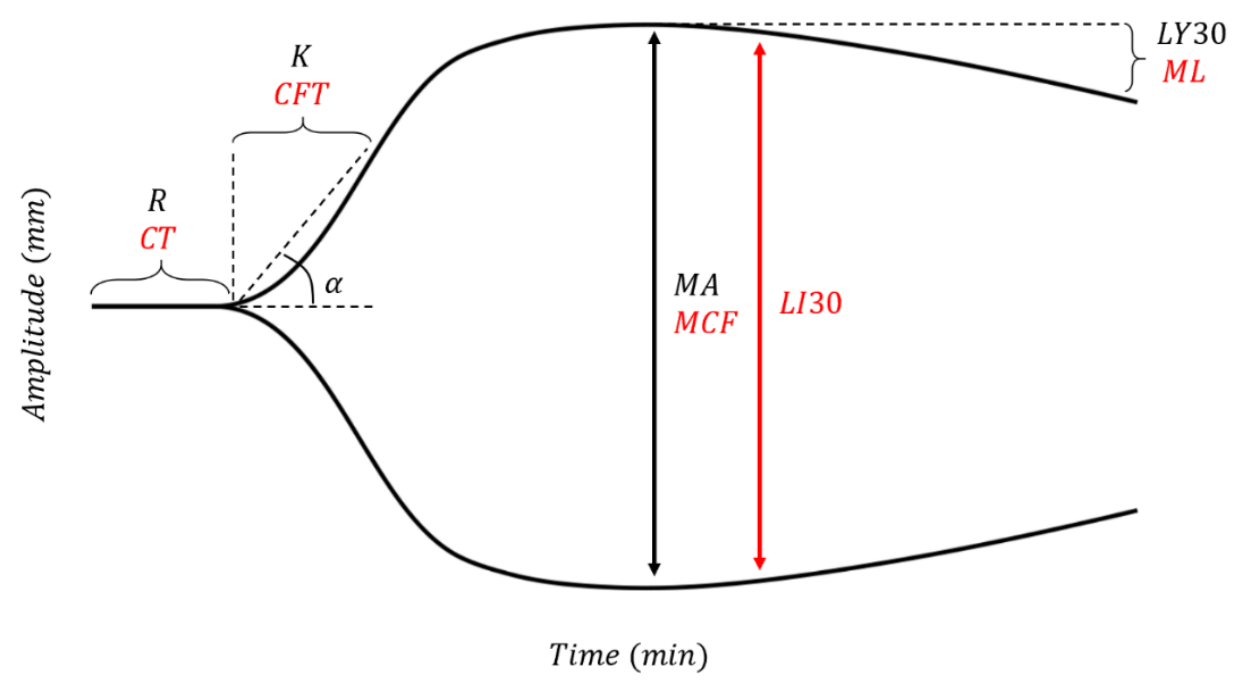

Figure 2. A typical graphical output of TEG ${ }^{\circledR}$ (parameters shown in black) and ROTEM ${ }^{\circledR}$ (parameters shown in red). R (Reaction Time)/CT (Clotting Time) denotes the time taken for blood to begin initiation of enzymatic clotting factor activation (marked by a movement of $2 \mathrm{~mm}$ along the $y$-axis). K/CFT (Clot Formation Time) denotes the time taken for movement of the pin by $20 \mathrm{~mm}$ along the $y$-axis. The $\alpha$-angle is software-calculated using the slope of the secant line from the split point of the curve to K [111]. Clot kinetics are typically determined by $\mathrm{K}$ and $\alpha$-angle, which together describe clot-strengthening rate and the cleavage of fibrinogen to fibrin by thrombin. Maximum Amplitude (MA) or Maximum Clot Firmness (MCF) denotes the peak of the curve and the point of greatest platelet-fibrin interaction [105,107]. Lysis at $30 \mathrm{~min}$ (LY30) is measured $30 \mathrm{~min}$ after MA as a percentage dissolution from MA peak. LI30 (Lysis Index at 30min) is measured as the amplitude $30 \mathrm{~min}$ after CT. Maximum Lysis (ML) is expressed as a percentage dissolution from MCF peak at the time of evaluation during the performance of the test and is roughly equivalent to the LY30 [43,106-108,112].

ROTEM $^{\circledR}$ also has its own platelet functionality testing called PLTEM, which has not been studied in TBI and is rarely used in the setting of polytrauma [113-115]. In PLTEM, the A10 parameter represents the amplitude of the tracing $10 \mathrm{~min}$ after the end of CT. PLTEM calculates the difference between the EXTEM A10 (A10 EX) and the FIBTEM A10 $\left(\mathrm{A} 10_{\mathrm{FIB}}\right)$. The $\mathrm{A} 10_{\mathrm{EX}}$ represents the clot strength of the entire extrinsic pathway and the A10 $\mathrm{FIB}$ represents the same pathway but without the contribution by platelets. Thus, the PLTEM represents the contribution of platelets to clot strength. Reporting the PLTEM parameter would likely involve manually calculating and extracting A10 data from each assay $[115,116]$. For those situations where TEG-PM ${ }^{\circledR}$ and PLTEM are not available, ROTEM ${ }^{\circledR}$ has adopted an accompanied MEA platform, also known as MultiPlate ${ }^{\circledR}$, for determining activity of platelet function in TBI. The MultiPlate ${ }^{\circledR}$ analyser-after the platelets are activated by a specific agonist in each well, such as ADP, AA, ristocetin, collagen, or thrombin receptor activating peptide (TRAP) — operates by the platelets adhering to the electrodes and reducing impedance (Figure 5). Platelet aggregation and activation are described as an area under the curve in relation to a standard control baseline. This MEA test is not a viscoelastic test but is used as an adjunct with ROTEM $^{\circledR}$ to isolate platelet dysfunction $[39,65,66,87,117-119]$. Intradevice variability is low for TEG-PM ${ }^{\circledR}$ and MultiPlate, but the measurement of platelet function overall correlates poorly in injured trauma patients [120]. 

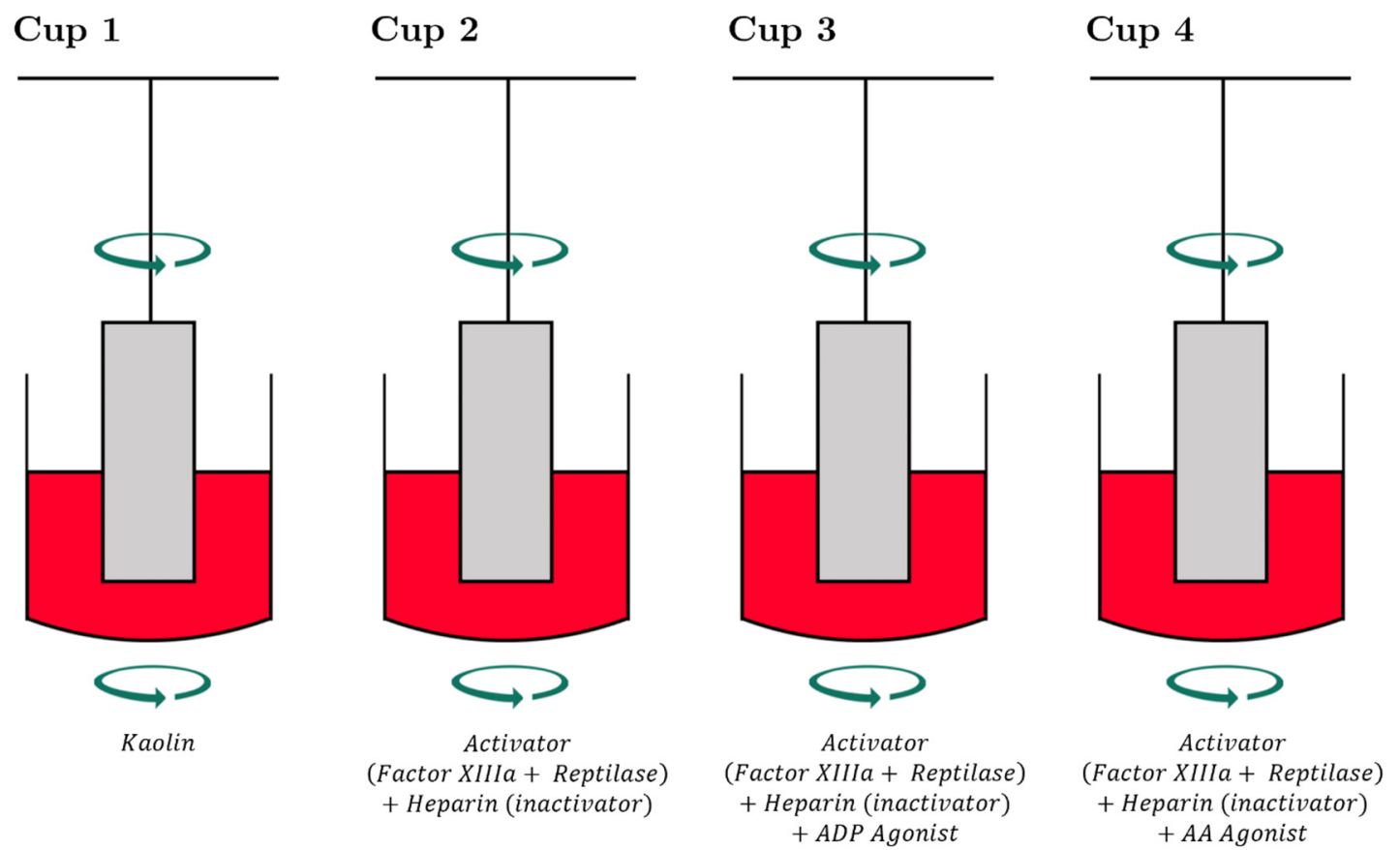

Figure 3. The analysis of platelet function requires four cups for Modified Thromboelastography with Platelet Mapping $\left(\right.$ TEG-PM ${ }^{\circledR}$ ). In Cup 1 is a baseline kaolin TEG ${ }^{\circledR}$ which describes control parameters. In Cups $2-4$, heparin is added to neutralize thrombin which allows for isolation of platelet function in the presence of a pure fibrin clot. Reptilase and Factor XIIIa are added to Cups 2-4 to enhance fibrinogen and fibrin formation. Therefore, the additions of ADP in Cup 3 and AA in Cup 4 allow selective and respective activation of isolated ADP and AA receptors which then create an isolated pure fibrinogen/ fibrin-platelet clot $[109,121]$.

MEA is affected by platelet transfusion and COX inhibitor treatment. In TBI, MEA has demonstrated platelet dysfunction in patients with and without COX inhibition treatment. For those on platelet inhibitors-a common subset of TBI patients-MEA generally shows low values initially and increases within 48-72 h [39,122,123]. However, compared with antiplatelet agents, later studies of platelet transfusions showed no significant difference in outcome [124,125]. Hence, the substantial heterogeneity in results regarding the efficacy of platelet transfusion for TBI with and without preinjury antiplatelet therapy remains an area of fertile research and controversy [126].

In addition, other non-viscoelastic assays have been added as adjuncts to assist in the determination of the adequacy of platelet function for these patients. These electrochemical and biochemical tests, including PFA-100 and VerifyNow Aspirin/P2Y12 assays, have been adapted from the cardiology and neurological population of patients whose blood required determination of platelet inhibition following administration of antiplatelet agents. These tests have demonstrated heterogeneous results when used to gauge platelet dysfunction following TBI for patients with or without preinjury antiplatelet medications $[2,63,72,74,120]$. Notably, these assays have several shortcomings, including limited availability and methods that have not been subject to large-scale quality control. The tests themselves are of little value in cases of low platelet counts. The assay-based monitoring of direct oral anticoagulant (DOAC) effectiveness is also in its infancy. The utilization and application of whole blood POC assays are still not universally practiced in trauma [127]. 


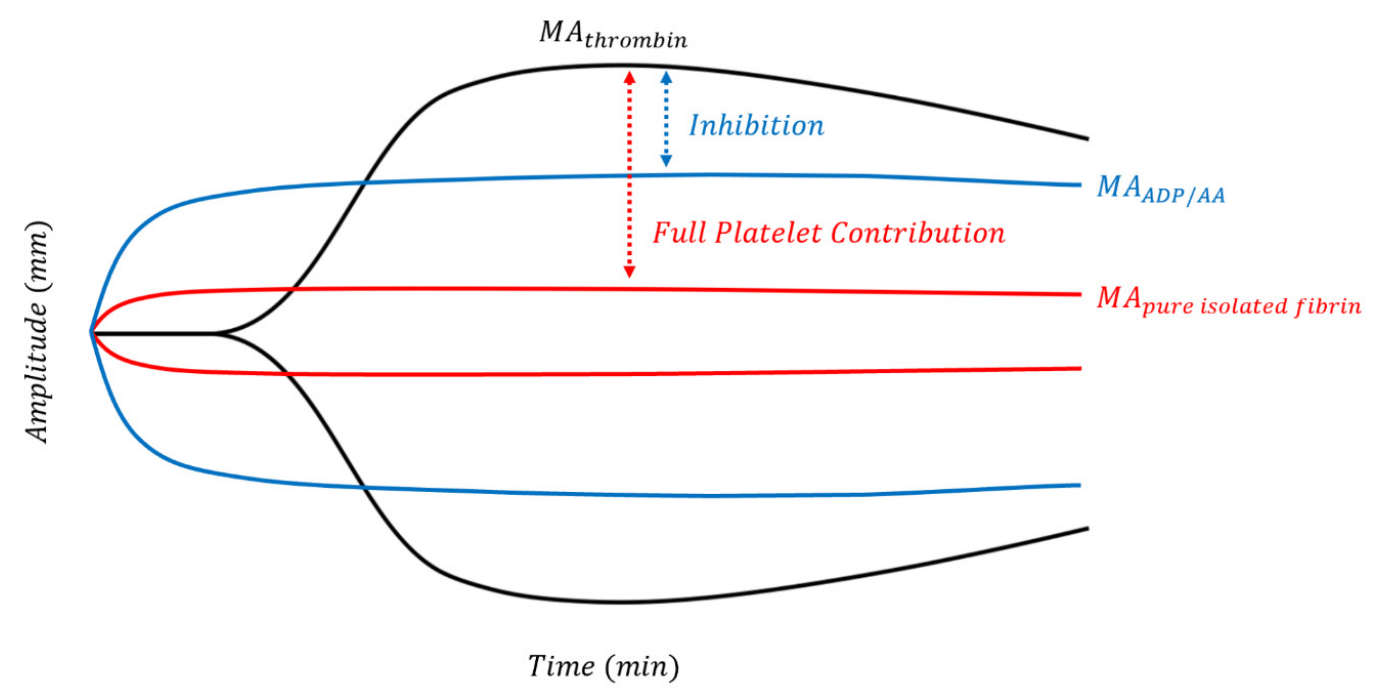

Figure 4. The $\mathrm{TEG}^{\circledR}$ PlateletMapping assay is composed of four tests, starting with a standard kaolin TEG ${ }^{\circledR}$ (black line; corresponds to Cup 1 of Figure 3 ) that depicts maximally activated platelets and full clot strength potential ( $\left.\mathrm{MA}_{\text {thrombin }}\right)$. The clot strength of pure fibrin (red line; corresponds to Cup 2 in Figure 3) is isolated after blockage of all thrombin in the second test. Platelets are then activated in the third and fourth tests through either their ADP or AA receptors, and clot strength of platelets activated at either receptor (blue line; corresponds to Cups 3 \& 4 in Figure 3) is evaluated by the proximity of the stimulated platelet as a percentage of $\mathrm{MA}_{\text {thrombin }}$ [128]. The platelet inhibition in response to the agonist is calculated from platelet aggregation: $\left[\left(\mathrm{MA}_{\mathrm{ADP}}-\mathrm{MA}_{\text {fibrin }}\right) /\left(\mathrm{MA}_{\text {thrombin }}-\mathrm{MA}_{\text {fibrin }}\right) \times 100\right]$ and $\%$ inhibition $=(100-\%$ aggregation $)[109]$.

\section{Utilizing VETs for the Diagnosis and Treatment of TBI}

There are three main areas in which TEG ${ }^{\circledR}$ has been used to analyze TBI, representing the stages of clinical evaluation assisted by VETs: diagnosis of CTBI, management of CTBI, and prognosis of TBI [4,23,129-132].

\subsection{VETs to Diagnose, Treat, and Prognosticate CTBI \\ 4.1.1. Diagnosis of CTBI}

TEG $^{\circledR}$ and TEG-PM ${ }^{\circledR}$ reportedly assist in diagnosis and differentiation between coagulopathies of TBI and non-TBI patients. TEG ${ }^{\circledR}$ and ROTEM $^{\circledR}$ parameter have been found to add sensitivity to the diagnosis of CTBI with abnormalities of all parameters reported $[5,37,53,60,86,100,110,133-139]$.

\subsubsection{Treatment of CTBI}

TEG $^{\circledR}$ and TEG-PM ${ }^{\circledR}$ can be used to guide the diagnosis and treatment of patients with CTBI $[53,61,62,64,129,140-143]$. These TEG-guided therapies enable physicians to quickly deliver focused therapies, accurately correcting coagulopathy while potentially conserving blood products. Still, there are heterogeneous and conflicting results regarding whether application of VETs like TEG ${ }^{\circledR}$ correlate with improved patient outcomes and reduced mortality $[1,39,40,84,86,123,129,140,141,144-146]$. Several studies exhibit improved survival when using a TEG-based resuscitation strategy compared to a CCA-guided treatment (PT, aPTT, fibrinogen, and D-dimer) $[56,139,147]$.

For example, a TEG-based resuscitation strategy was shown to improve survival in a pragmatic randomized controlled trial as compared to one based on CCAs; however, subgroup analysis on TBI patients did not demonstrate reduced mortality. It should be noted that the TBI subgroup was not specified a priori nor sufficiently powered for this outcome [129]. In addition, the iTACTIC study indicated possible improvement and survival in the subgroup of injured multiple trauma patients with TBI whose resuscitation was guided by ROTEM $^{\circledR}$ with specific emphasis on FIBTEM-guided resuscitation using soluble fibrinogen concentrate [140]. Improved clot quality with decreased neurosurgi- 
cal reintervention and decreased incidence of progressive hemorrhagic injury PHI has been noted with ROTEM ${ }^{\circledR}$ [45]. Delayed clot formation without associated fibrinolytic abnormalities is a singular manifestation of the unique hemostatic derangement of severe isolated TBI. Activated coagulation time (ACT) when prolonged, and coupled with low fibrinogen levels, suggest that early coagulation factor replacement may be more critical than empiric antifibrinolytic therapy. It is clear the mechanisms that precipitate coagulopathy in TBI differ from those mechanisms in multisystem trauma and warrant further investigation [60].

\section{Multiplate ${ }^{\circledR}$}

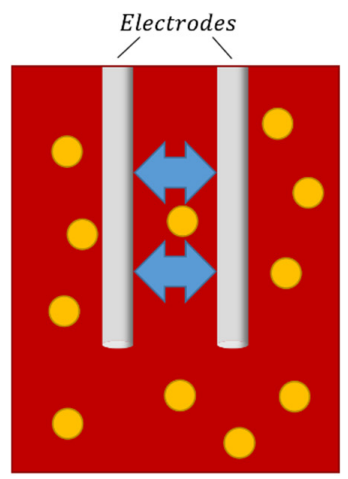

No Activation

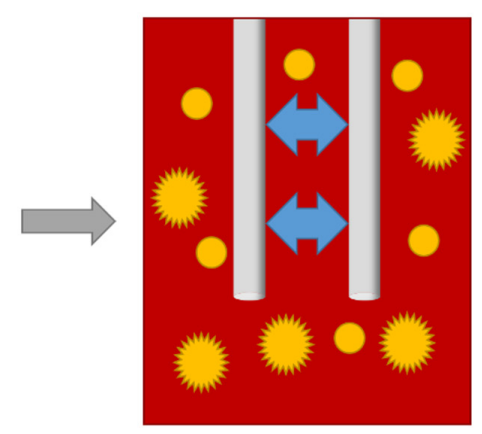

Partial Activation
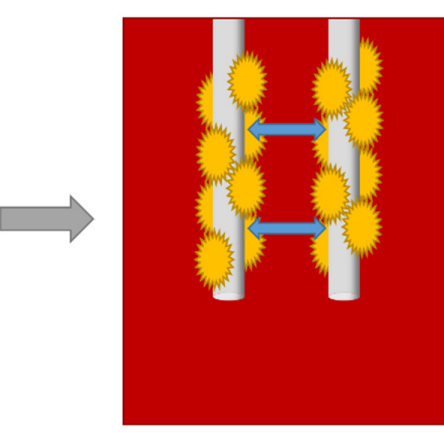

Full Activation

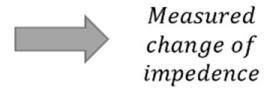

impedence

Figure 5. The Multiplate ${ }^{\circledR}$ multiple electrode impedance aggregometer measures platelet function in diluted anticoagulated whole blood. Each plate uses two sensors containing a pair of silver-coated copper wire electrodes. Over a set duration of time, aggregation of activated platelets on the surface of the electrodes causes a measurable change in impedance, measured in aggregation units $(\mathrm{AU}$, where $8 \mathrm{AU} \approx 1 \Omega$ ) and area under the AU curve [148].

It has also been suggested that POC testing with platelet function analysis be used to manage TBI patients who need extracorporeal membrane oxygenation [149].

\subsubsection{Prediction of Morbidity and Mortality in CTBI}

TEG $^{\circledR}$ and TEG-PM ${ }^{\circledR}$ assays can predict a range of clinical outcomes in patients with CTBI, including bleeding complications, mortality, and neurosurgical intervention $[1,3,56,72,84,86,139,144,145,150-153]$. However, Rapid TEG ${ }^{\circledR}$ parameters have been associated with the increased odds of hematoma expansion in patients with TBI and SAH [153].

Several studies have demonstrated that TBI patients are significantly more hypercoagulable at presentation, likely due to increased platelet aggregation. Moreover, initial hypercoaguability determined by TEG ${ }^{\circledR}$ in TBI patients was associated with prolonged ICU stays, longer overall hospital admissions, and increased mortality [3,5,53,56,64,110,135-137]. TBI patients with initial hypocoagulopathic $\mathrm{TEG}^{\circledR}$ values (longer reaction times, flat alpha angles, thin MAs) highly correlate with mortality in isolated TBI [86].

Standard TEG ${ }^{\circledR}$ assays conducted at admission and after $6 \mathrm{~h}$ of hospitalization on TBI patients have been able to identify patients who will experience worse clinical outcomes. $\mathrm{TEG}^{\circledR}$ monitors the rate of clot breakdown in addition to clot formation: an increased rate of fibrinolysis and abnormal clot formation identifies those patients who may require a neurosurgical procedure or have a greater risk of worse mortality [152]. In addition, prognosis and progression of intracranial bleeding are dependent on coagulopathy identified by admission TEG ${ }^{\circledR}$ parameters but not CCAs $[3,40,82,86,139,154]$.

\subsection{Basic TEG $G^{\circledR} /$ ROTEM $^{\circledR}$ Parameters Triggering $B C T$ and $H A T$}

Prolongation of reaction time (R) in TEG ${ }^{\circledR}$ or clotting time (CT) in ROTEM ${ }^{\circledR}$ indicates a coagulation factor deficiency and warrants fresh frozen plasma (FFP) and/or prothrombin 
complex concentrate administration $[47,155]$. A prolonged clot formation/kinetics (K) in $\mathrm{TEG}^{\circledR}$ or clot formation time (CFT) in ROTEM ${ }^{\circledR}$ and a low a-angle reflect a fibrinogen or fibrin production deficiency, warrants cryoprecipitate or fibrinogen concentrate administration. A low maximum amplitude (MA) in TEG ${ }^{\circledR}$ or maximum clot formation $(\mathrm{MCF})$ in ROTEM ${ }^{\circledR}$ depicts decreased clot formation and warrants platelet repletion. An increase in lysis at $30 \mathrm{~min}$ (LY30) in TEG ${ }^{\circledR}$ or a decrease in lysis index at $30 \mathrm{~min}$ (LI30) suggests fibrinolysis and is treated with an antifibrinolytic agent [43,44,105-107,155-158]. Currently, thresholds for platelet administration to patients with TBI are in a state of evolution $[23,40,52,61,63,64]$.

\subsection{Guiding Blood Products with VETs in TBI}

Recommended thresholds have been proposed regarding VETs for guiding the administration of blood components and hemostatic therapy for hemorrhaging trauma patients without TBI $[46,47,63,80,159,160]$. A preliminary study by Furay et al. suggested improved survival in TBI patients with VET-guided BCT resuscitation [61]. For example, as mentioned above, the 2021 ITACTIC study suggests that survival of TBI patients may be improved with the use of VET-guided treatment algorithms [140]. For patients with TBI, whether isolated or associated with multiple trauma, increased survival rates could be a product of individually-tailored and prompt administration of blood products, which, as we have demonstrated, can be appropriately guided by VETs [129]. An analysis in the Prehospital Air Medical Plasma (PAMPer) trial upheld this conclusion, finding that a subgroup of TBI patients exhibited increased survival with the administration of pre-hospital plasma guided by the TEG ${ }^{\circledR}[161,162]$. Reductions in cerebral inflammation, intracerebral bleeding, and cerebral ischemia are attained using a targeted management approach, thus potentially contributing to the documented improvement in survival [140].

\subsubsection{VET-Guided FFP, Fibrinogen Concentrate, and Cryoprecipitate in TBI}

The use of FFP in patients with moderate and severe TBI is under investigation [163-165]. Both empirical infusion of FFP in severe-TBI patients and use of FFP in patients with TBI and moderate coagulopathy (with or without $\mathrm{pRBCs}$ ) have been associated with poor functional outcomes [125]. However, there are survival benefits with early FFP administration in patients with multifocal intracerebral hemorrhage (ICH) [163] or with ratio-based blood-product transfusion in patients suffering from TBI when guided by the TEG ${ }^{\circledR}$ and ROTEM $^{\circledR}[129,140,165]$.

A plasma-based coagulation resuscitation strategy also suggests that such administration should be avoided in patients without substantial bleeding [46]. Instead, in such cases, it has been found that therapy guided by TEG ${ }^{\circledR}$ using PCC and fibrinogen concentrate for treatment is more advantageous than FFP use $[6,23,44,140,166]$. Fibrinogen concentrates are efficient and should be used primarily for those patients with bleeding complications. If unavailable, FFP or cryoprecipitate may be used instead. Replenishment of fibrinogen can be guided by ROTEM ${ }^{\circledR}$ MCF values [167].

Fibrinogen is defined as the substrate for clot formation, playing a key role in hemostasis through conversion to fibrin, undergoes crosslinking, and interacts with platelets [168]. TBI causes coagulation factor consumption to significantly increase; in tandem, this causes consumption of fibrinogen. Fibrinogen concentrations thereafter do not recover beyond normal amounts until at least 2-3 days after the initial TBI [169]. Significantly reduced fibrinogen concentrations in the initial phase following an injury not linked to TBI have also been observed to be associated with high rates of mortality [170]. Due to this linkage, concentrations should remain within 1.5-2 g/L through the utilization of either cryoprecipitate or fibrinogen concentrates [46]. Late-stage TBI can also cause plasma concentrations of fibrinogen to increase. This increase in fibrinogen-which is an acute phase reactant and a marker of post-resuscitative inflammation - is a late compensatory reaction to the previously hypocoagulopathic state for patients with severe TBI, which is similar to the increase in fibrinogen found in any patient in the period of recovery following successful 
resuscitation after hemorrhage [171]. This increase in plasma fibrinogen as a marker of inflammation correlates with an increase in cerebrovascular permeability and a resultant injury to the penumbra that ultimately serves as a gateway to further inflammation [171].

As a result of the above-mentioned studies, the most recent European guidelines recommend utilization of VETs to guide FFP, fibrinogen concentrate, and cryoprecipitate for TBI [47].

\subsubsection{VET-Guided Diagnosis and Treatment of Platelet Dysfunction in TBI}

Platelets' function consists of adhesion, activation, and aggregation which initiate the action of coagulation factors to reach hemostasis. TF initiates coagulation and platelets contribute to enhance the reaction by providing a negatively charged surface which allows adhesion, activation, and aggregation. Their enhancement of coagulation with tissue damage and TF release as a trigger, therefore plays an important role in the pathophysiology of TBI.

TBI affects both platelet number and function [40]. Low platelet count $\left(<100,000 / \mathrm{mm}^{3}\right)$ has been shown to be an independent predictor of mortality in TBI patients [172]. However, as has been described above in the section on pathophysiology, platelet dysfunction at the ADP and AA receptors (as measured by the TEG-PM ${ }^{\circledR}$ ) reflects the severity of TBI even with patients with normal platelet counts. In addition, ROTEM ${ }^{\circledR}$ using the MEA and the VerifyNow P2Y12 to quantify platelet dysfunction in TBI has demonstrated similar dysfunction at the AA and ADP receptors as well as the ristocetin, PAR1, and collagen platelet receptors in patients with TBI $[1,53,56,60,65,83-87]$. Furthermore, the TEG-PM ${ }^{\circledR}$ showed elevated ADP inhibition, which is further linked with increased mortality, when measured directly after an isolated blunt TBI [144]. The TEG-PM ${ }^{\circledR}$ was also successful at reporting elevated ADP inhibition with increasing injury severity. This correlation between the severity of injury and the level of inhibition of the predominate ADP receptor has been defined as the "dose-response curve" describing the relationship between the level of injury dose and the response to that injury as determined by ADP inhibition response [52,64]. As a result, it has been noted that TBI patients with severe (greater than $60 \%$ ) ADP inhibition had increased mortality compared to other TBI patients with less ADP inhibition [151]. In parallel, TBI patients who suffered from a bleeding event had a higher AA inhibition compared to other TBI patients [84]. A weak correlation was established between TEG-PM's AA inhibition measure and $\mathrm{ICH}$ progression when there was no significant correlation for other platelet assays such as Multiplate aggregometry and VerifyNow ${ }^{\mathrm{TM}}$ [72].

It is still unclear whether the presence of ADP inhibition in this patient population is a prognostic indicator or a therapeutic target [61].

Trauma-induced platelet dysfunction can be corrected using TEG-PM ${ }^{\circledR}$ to guide the treatment plan. A TEG-PM ${ }^{\circledR}$ based algorithm has been found to significantly decrease the number of platelet transfusions needed for older TBI patients who are on anti-platelet medications [4,82]. Patients with platelet dysfunction on admission suffering from severe TBI have also been studied $[1,53,61,83,84,86,87]$. Using a protocol, platelet dysfunction was demonstrated by an ADP-inhibition of greater than $60 \%$. These patients received one unit of apheresis platelets and exhibited decreased mortality compared to patients who were not given these platelets. Furthermore, the use of TEG-PM ${ }^{\circledR}$ was able to limit the total overall administration of blood products efficiently $[61,86]$. TBI-associated platelet transfusion remains controversial. Moderate thrombocytopenia outcomes were not improved by post TBI platelet concentrate transfusions [125]. Additionally, platelet transfusions performed on patients undergoing antiplatelet therapy at the time of a mild TBI occurrence failed to improve outcomes, but evidence may link this with thrombotic complications. Currently, retrospective registry studies have failed to show that patients undergoing antiplatelet preinjury would benefit from routine platelet transfusions after sustaining traumatic ICH [49,124].

Despite significant literature that demonstrates platelet dysfunction associated with TBI for patients with and without preinjury and antiplatelet use, there is little consensus 
regarding the indication for the administration of platelets for those patients. Observational and retrospective studies have shown some benefit when platelet transfusion is guided by TEG-PM ${ }^{\circledR}$ and ROTEM $^{\circledR}$ with MEA, PFA, or VerifyNow P2Y12. This remains an area of significant research since the administration of platelets in these patients is now determined locally by institutional preferences with variable use of TEG-PM ${ }^{\circledR}$ and ROTEM ${ }^{\circledR}$ with adjunctive PFAs [23,39,58,74,173-175].

In addition, the increased use of anticoagulants and antiplatelet agents in patients with TBI has led to widespread and institution-dependent platelet transfusion with such injuries $[23,40,52,61,63,64]$. There are many side effects that can occur with platelet transfusion which makes this practice controversial, such as sepsis, transfusion-related acute lung injury, blood group type incompatibility reactions, arrhythmia, stroke, and death $[176,177]$. Hence, in patients who suffer from TBI and are taking antiplatelet medication, the advantages and disadvantages of platelet transfusion need to be carefully considered before platelet transfusions are administered.

A plethora of assays has demonstrated that aspirin causes a decrease in platelet aggregation. The Aspirin Response Test is used to show the impact of aspirin on platelet function and has determined that $64 \%$ of TBI patients on aspirin who have been administered platelets have a reversal of platelet inhibition [74]. However, the adverse effects of transfusing platelets may outweigh the benefits of the physiological response. When assessing mortality in patients with TBI who received a platelet transfusion versus those who did not receive a platelet transfusion, there was no significant difference in mortality between the two groups. In addition, increased mortality was observed when patients on pre-injury antiplatelets were given platelets for TBI related coagulopathy. As severity of injury increased, the transfusion rate of platelets increased as well [178]. No significance was found between platelet transfusion and need for surgical intervention, rate of neurologic decline, progression of injury based on GCS, cardiac events, respiratory events or imaging [179]. A multi-institutional observational study found that aspirin-related platelet inhibition was significantly decreased with platelet transfusion. However, platelet transfusions did not impact mortality of these TBI patients [142]. Platelet transfusion may seem to be an intuitive therapy for platelet dysfunction, but for TBI patients on antiplatelet agents, it is not effective at improving outcomes [146]. The large PATCH trial recently has demonstrated increased mortality in patients on antiplatelet agents who had TBI. This study hypothesized that whatever benefit accrued from the administration of platelets in patients on antiplatelet agents with TBI were counteracted by the effect of a local hypercoagulable state at the microvasculature in the penumbra of injured brain tissue. For this reason, and for the smaller studies that demonstrate the benefit of VET guided platelet transfusion in patients with TBI and platelet dysfunction, there is increased interest in not only the use of VET to guide platelets in patients with TBI and preinjury antiplatelet agents, but also in using desmopressin to enhance platelet function in these patients $[23,52,58,61,126,144,173-175,180]$. DDAVP has been shown to stabilize platelet dysfunction in neurosurgical patients and those with spontaneous ICH with abnormal platelet activity who were previously on aspirin. Because of the heterogeneous reports regarding the incidence of platelet dysfunction in isolated TBI for patients with and without prior antiplatelet agents, further research is clearly indicated regarding the incidence of platelet dysfunction in this population and whether replenishment of platelets and/or desmopressin is of therapeutic benefit $[62,82,173,181,182]$.

Other studies have compared the use of desmopressin to platelet transfusion in patients with severe TBI. Both treatments were found to improve ADP inhibition similarly while displaying no differences in mortality. However, treatment with platelets did exhibit $\mathrm{TEG}^{\circledR}$ parameters $(\alpha, \mathrm{G}, \mathrm{MA})$ that were corrected to a greater degree, and a greater increase in clot strength $[62,83]$. Platelet transfusion has also been shown to improve AA inhibition specifically in patients with blunt TBI who were taking antiplatelet agents prior to injury. However, no improvement in mortality was seen with this treatment [142,152]. 
The above-mentioned studies concerning the use of VETs with and without adjunctive platelet function tests demonstrate heterogeneous results, which has resulted in institutional preferences for guiding platelet transfusion for patients with TBI (Table 1).

Table 1. Studies using modified VETs or VETs with adjunctive platelet function analyses in TBI. AA, arachidonic acid; ADP,

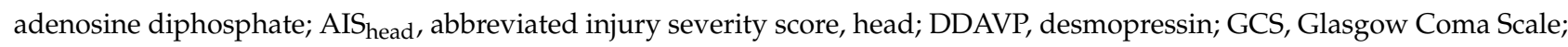
INR, international normalized ratio; ISS, injury severity score; MEA, multiple electrode aggregometry; ROTEM, rotational thromboelastometry; TBI, traumatic brain injury; TEG-PM, thromboelastography with platelet mapping; TRAP, thrombin receptor activating peptides; VET, viscoelastic test.

\begin{tabular}{|c|c|c|c|}
\hline Reference & Study Design (VET Used) & No. of Patients & Conclusions \\
\hline Nekdulov et al., 2007 [84] & $\begin{array}{l}\text { Prospective Observational } \\
\text { (TEG-PM) }\end{array}$ & $\begin{array}{c}20 \text { isolated TBI } \\
(\text { GCS }<8 \\
\text { AIS-non-head } \leq 3)\end{array}$ & $\begin{array}{l}\text { TBI patients had } 78 \% \text { AA } \\
\text { inhibition compared to } 27 \% \text { AA } \\
\text { inhibition for healthy controls. } \\
\text { The } 8 / 20 \text { TBI patients that bled } \\
\text { had a significantly greater AA } \\
\text { inhibition than nonbleeders. }\end{array}$ \\
\hline Solomon et al., 2011 [65] & $\begin{array}{l}\text { Retrospective Observational } \\
\text { (ROTEM, MEA) }\end{array}$ & 163 polytrauma & $\begin{array}{l}\text { Mortality was correlated with } \\
\text { low platelet aggregation by } \\
\text { ADPtest, TRAPtest, and } \\
\text { ROTEM platelet component } \\
\text { contribution. }\end{array}$ \\
\hline
\end{tabular}

Patients with TBI had a median

Wohlauer et al., 2012 [83] $\quad \begin{gathered}\text { Retrospective Observational } \\ \text { (TEG-PM) }\end{gathered} \quad 10$ polytrauma TBI
ADP inhibition of $89.4 \%$ and Wohlauer et al., 2012 [83] $\quad \begin{array}{cc}\text { Retrospective Observational } \\ \text { (TEG-PM) }\end{array} \quad 10$ polytrauma TBI median AA inhibition of $40.1 \%$ despite normal platelet counts and INR.

$\begin{array}{cc}\text { Davis et al., } 2013 \text { [1] } & 50 \text { isolated TBI } \\ \text { Retrospective Observational } & (\text { AIS } \\ \text { (TEG-PM) } \geq 3, \\ \text { AIS-non-head }<2)\end{array}$

The median ADP inhibition was $>91.7 \%$ for nonsurvivors vs. $48.2 \%$ for survivors; however, this difference was not statistically significant.

The median ADP receptor inhibition of all TBI patients

$\begin{array}{cc}\text { Castellino et al., 2014 [53] } & \begin{array}{c}70 \text { isolated TBI } \\ \text { Retrospective Observational } \\ \text { (TEG-PM) }\end{array} \\ \text { AIS-non-head }<2 \text { head } \geq 3,\end{array}$
was $64.5 \%$ vs. $15.5 \%$ in controls.
For GCS $\leq 8$, the median ADP AIS-non-head <2) inhibition was $93.1 \%$ vs. $56.5 \%$ for those with GCS > 8. The median AA inhibition of all TBI patients was $25.6 \%$ vs. $2.2 \%$ in healthy controls.

Patients with ADP inhibition on TEG-PM had a higher in-hospital mortality rate ( $8 \%$ vs. $32 \%)$. After controlling for age,

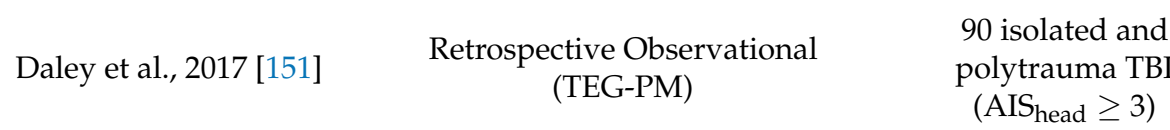
gender, hypotension, GCS, ISS, and preinjury antiplatelet use, ADP inhibition $>60 \%$ demonstrated a significant odds ratio for mortality. AA inhibition $>60 \%$ was not found to be significant.

Patients who received TEG-PM guided goal-directed platelet transfusion for ADP inhibition

Retrospective Case-Control (TEG-PM)
35 isolated and polytrauma blunt TBI $\left(\right.$ AIS $_{\text {head }} \geq 3$ )
$>60 \%$ had a significantly lower mortality compared to those who received no platelet transfusions ( $9 \%$ vs. 35\%). 
Table 1. Cont.

\begin{tabular}{|c|c|c|c|}
\hline Reference & Study Design (VET Used) & No. of Patients & Conclusions \\
\hline Guillotte et al., 2018 [64] & $\begin{array}{c}\text { Retrospective Observational } \\
\text { (TEG-PM) }\end{array}$ & 153 TBI & $\begin{array}{l}\text { ADP inhibition was greater in } \\
\text { moderate/severe TBI compared } \\
\text { to mild TBI. ADP inhibition was } \\
\text { not found to be associated with } \\
\text { mortality or intracerebral lesion } \\
\text { expansion. There was no } \\
\text { significant difference in the } \\
\text { reduction of ADP inhibition } \\
\text { with platelet transfusion } \\
\text { compared to patients who did } \\
\text { not receive platelet transfusion. }\end{array}$ \\
\hline Kay et al., 2019 [144] & $\begin{array}{l}\text { Retrospective Observational } \\
\text { (TEG-PM) }\end{array}$ & $\begin{array}{l}119 \text { isolated TBI } \\
\quad(\text { AIS } \\
\text { head } \geq 3 \\
\text { AIS-non-head }<2)\end{array}$ & $\begin{array}{l}\text { The median ADP inhibition was } \\
\text { 18.4 points higher in severe TBI } \\
\text { (AIS head }=4 \text { or } 5 \text { ) compared to } \\
\text { moderate TBI (AIS head }=3 \text { ). } \\
\text { Increased degree of ADP } \\
\text { inhibition was also associated } \\
\text { with increased odds of } \\
\text { in-hospital mortality. }\end{array}$ \\
\hline Furay et al., 2020 [62] & $\begin{array}{l}\text { Retrospective Observational } \\
\text { (TEG-PM) }\end{array}$ & $\begin{array}{l}57 \text { isolated and polytrauma } \\
\text { blunt TBI with ICH } \\
\left(\text { AIS }_{\text {head }} \geq 3\right)\end{array}$ & $\begin{array}{l}\text { There was no difference in } \\
\text { post-treatment ADP inhibition } \\
\text { levels whether DDAVP alone or } \\
\text { platelets alone were } \\
\text { administered, guided by } \\
\text { TEG-PM ADP inhibition > } 60 \% \\
\text { as threshold for therapy. There } \\
\text { was no significant difference in } \\
\text { all-cause mortality between the } \\
\text { two treatment groups. }\end{array}$ \\
\hline
\end{tabular}

\subsection{Preinjury Antithrombotic Use}

Since the TEG ${ }^{\circledR}$ and ROTEM ${ }^{\circledR}$ have been mostly used for patients with multiple trauma who need immediate BCT and HAT, there has been sparse literature for VET in TBI for a small group of patients who are on anticoagulants such as warfarin and DOACs. While it is well known that TEG ${ }^{\circledR}$ and ROTEM $^{\circledR}$ do not measure warfarin or DOACs hemostatic activity, the existing literature is limited to a few studies of modified VETs that allow for analysis but are not used clinically.

Increased incidence of patients with comorbidity is observed as the TBI demographic switches to an older age [122,183]. Modern treatment of coronary artery and chronic cerebrovascular disease indicates a need for these patients to take antiplatelet or anticoagulant drugs; both of which are associated with increased bleeding and, ultimately, worsened TBI outcomes [122,184-189]. Meta-analysis on 49 patients supplementing warfarin at the occurrence of TBI shows that the risk of poor outcome is double that of those not supplementing warfarin. However, similar demographic analysis on patients supplementing antiplatelet therapy did not indicate a clear increase in risk to those not undergoing antiplatelet therapy $[184,188,189]$. Additional retrospective evidence reiterates this observation [186], yet other studies argue that antiplatelet therapy supplementation preinjury, especially in an older demographic, could result in nearly a twofold increase in the occurrence of traumatic ICH even after minor TBI, when compared with patients not supplementing antiplatelet therapy at the time of the injury $[185,190,191]$. Preinjury warfarin or clopidogrel are independent factors from the severity of TBI for prediction of disease progression, $\mathrm{ICH}$, and worse prognosis $[36,124,185,192,193]$. Currently, the risks that patients supplementing newer, target-specific DOACs endure in the face of TBI is unknown [194]. Though these 
treatments are known to lower the risk of spontaneous non-traumatic ICH, the validity of their use in TBI has been inadequately quantified. Retrospective study results [194-196] provided the earliest evidence for less operative interventions and decreased mortality in patients with blunt traumatic ICH associated with preinjury supplementation of DOACs rather than warfarin. Other common drugs such as selective serotonin reuptake inhibitors might also influence hemostasis [197]; however, their effect on TBI outcomes remains inadequately studied.

When comparing the blood product usage in anti-coagulated trauma patients with and without TEG-guided administration, blood product use was significantly lower when utilizing a TEG-guided approach; this is statistically independent from the mortality rates in both groups as they were extremely comparable [141]. In other words, a TEG-guided approach to reversing anticoagulation in TBI patients may improve the efficiency of blood product usage without harmfully affecting mortality [141]. Cartridge-based modified $\mathrm{TEG}^{\circledR}$ with anti-Xa and direct thrombin inhibitor channels can provide DOAC levels within minutes [127]. Likewise, very recent ClotPro specific DOAC channels have been used to also determine levels of DOACs at the bedside in a comparatively short time. However, clinical research is still in its infancy for these tests. Although, it would be quite useful to know for patients with TBI, the patient's hemostatic competence of those on DOACs [198]. The use of PCC to reverse anti-Vitamin K oral antagonists in emergencies is a well-defined practice [47]. Bleeding complications seen with vitamin-K antagonists can be reduced through the use of DOAC-specific reversal agents. Beginning in 2015, Idarucizumab became available as a target reversal agent for dabigatran, a thrombin inhibitor [196]. Additionally, the reversal agent for factor Xa-inhibitors, andexanet alfa, has been recently introduced [72]. As mentioned above, to date there are few studies evaluating the new reversal agents with VETs [198].

\section{Conclusions}

In this review, we provide a detailed description of the literature regarding the utility of VETs in the diagnosis and treatment of CTBI. The management of CTBI patients is complicated by the scarcity of clinical data regarding the underlying pathophysiology and standard treatment strategies for CTBI [23,48,199,200].

Analysis of the benefits of VET-guided management of TBI and CTBI is in its infancy, yet it is important to acknowledge that significant gaps in knowledge persist. Similar gaps existed regarding the value of VETs to guide CT and HAT during trauma and hemorrhagic resuscitation of trauma and non-trauma situations, with a gradual affirmation of the utility of VETs in these situations, which has taken decades [42,201-206]. The degree of lesions in brain tissue and consequential hemostatic impairment contributes to the heterogeneity and complexity of a TBI injury, thus making it difficult to compare patients diagnosed with TBI. The inconsistent results produced in some studies documented in this review can, in part, be explained by this heterogeneity of TBI and of the methodology of defining CTBI. Thus, future studies ought to consider the heterogeneity of TBI and CTBI patients in their analyses. The pathophysiologic evolution of CTBI changes rapidly; therefore, collection and analysis of blood sampling must be quick and efficient. The most optimal time to do this for TBI and CTBI patients is promptly at emergency room admission. Finally, hemostatic interventions guided by TEG-PM ${ }^{\circledR}$, like administration of desmopressin and transfusion of platelet concentrate, to treat TBI-related platelet dysfunction and CTBI have not been subjected to rigorous analysis. The use of these strategies to treat patients with CTBI presents an interesting future in the history of VET-guided resuscitation for patients with CTBI.

Author Contributions: Conceptualization, S.G.T., N.B.P., K.A.S., S.M.S., W.S.L., D.H.F. and S.S.; resources, D.H.F. and S.S.; writing—original draft preparation, J.L.B., N.R.S., N.M., M.R.B., T.J.B., J.H.L., M.K.M., S.R.S., M.D.A.-F., Q.S., T.S., N.B.P., W.S.L. and S.S.; writing-review and editing, J.L.B., N.M., A.N.M., C.M.B., D.H.F. and S.S.; supervision, J.L.B., D.H.F. and S.S.; funding acquisition, D.H.F. All authors have read and agreed to the published version of the manuscript. 
Funding: No external funding was received for the writing or publication of this manuscript.

Institutional Review Board Statement: Not applicable.

Informed Consent Statement: Not applicable.

Conflicts of Interest: All the authors declare no conflict of interest.

\section{Abbreviations}

\begin{tabular}{|c|c|}
\hline $\mathrm{A} 10_{\mathrm{EX}}$ & EXTEM A10 \\
\hline $\mathrm{A} 10_{\mathrm{FIB}}$ & FIBTEM A10 \\
\hline AA & Arachidonic acid \\
\hline $\mathrm{ACT}$ & Activated coagulation time \\
\hline ADP & Adenosine diphosphate \\
\hline AIS & Abbreviated injury severity score \\
\hline AU & Aggregation units \\
\hline $\mathrm{BBB}$ & Blood-brain barrier \\
\hline CCA & Common coagulation assay \\
\hline CFT & Clot formation time (ROTEM parameter) \\
\hline $\mathrm{CT}$ & Clotting time (ROTEM parameter) \\
\hline CTBI & Coagulopathy of traumatic brain injury \\
\hline DDAVP & Desmopressin \\
\hline DOAC & Direct oral anticoagulant \\
\hline FFP & Fresh frozen plasma \\
\hline GCS & Glasgow Coma Scale \\
\hline $\mathrm{ICH}$ & Intracerebral hemorrhage \\
\hline INR & International normalized ratio \\
\hline ISS & Injury severity score \\
\hline $\mathrm{K}$ & Clot formation time (TEG parameter) \\
\hline LI30 & Lysis index at 30 min (ROTEM parameter) \\
\hline LY30 & Lysis at $30 \mathrm{~min}$ (TEG parameter) \\
\hline MA & Maximum amplitude (TEG parameter) \\
\hline $\mathrm{MCF}$ & Maximum clot firmness (ROTEM parameter) \\
\hline MEA & Multiple electrode aggregometry \\
\hline ML & Maximum lysis \\
\hline PAMPer & Prehospital Air Medical Plasma trial \\
\hline PAR-1 & Protease Activated Receptor-1 \\
\hline PFA & Platelet Function Analyzer \\
\hline POC & Point of care \\
\hline pRBCs & Packed red blood cells \\
\hline PT & Prothrombin time \\
\hline PTT & Partial thromboplastin time \\
\hline $\mathrm{R}$ & Reaction time (TEG parameter) \\
\hline ROTEM & Rotational thromboelastometry \\
\hline TBI & Traumatic brain injury \\
\hline TEG & Thromboelastography \\
\hline TEG-PM & Thrombelastography PlateletMapping \\
\hline $\mathrm{TF}$ & Tissue factor \\
\hline TRAP & Thrombin receptor activating peptides \\
\hline VET & Viscoelastic test \\
\hline vWF & von Willebrand factor \\
\hline
\end{tabular}

\section{References}

1. Davis, P.K.; Musunuru, H.; Walsh, M.; Cassady, R.; Yount, R.; Losiniecki, A.; Moore, E.E.; Wohlauer, M.V.; Howard, J.; Ploplis, V.A.; et al. Platelet dysfunction is an early marker for traumatic brain injury-induced coagulopathy. Neurocrit. Care 2013, 18, 201-208. [CrossRef]

2. Gozal, Y.M.; Carroll, C.P.; Krueger, B.M.; Khoury, J.; Andaluz, N.O. Point-of-care testing in the acute management of traumatic brain injury: Identifying the coagulopathic patient. Surg. Neurol. Int. 2017, 8, 48. [PubMed] 
3. Kunio, N.R.; Differding, J.A.; Watson, K.M.; Stucke, R.S.; Schreiber, M.A. Thrombelastography-identified coagulopathy is associated with increased morbidity and mortality after traumatic brain injury. Am. J. Surg. 2012, 203, 584-588. [CrossRef] [PubMed]

4. Kvint, S.; Schuster, J.; Kumar, M.A. Neurosurgical applications of viscoelastic hemostatic assays. Neurosurg. Focus 2017, 43, E9. [CrossRef] [PubMed]

5. Massaro, A.M.; Doerfler, S.; Nawalinski, K.; Michel, B.; Driscoll, N.; Ju, C.; Patel, H.; Quattrone, F.; Frangos, S.; Maloney-Wilensky, E. Thromboelastography defines late hypercoagulability after TBI: A pilot study. Neurocrit. Care 2015, 22, 45-51. [CrossRef] [PubMed]

6. Schöchl, H.; Solomon, C.; Traintinger, S.; Nienaber, U.; Tacacs-Tolnai, A.; Windhofer, C.; Bahrami, S.; Voelckel, W. Thromboelastometric (ROTEM) findings in patients suffering from isolated severe traumatic brain injury. J. Neurotrauma 2011, 28, $2033-2041$. [CrossRef]

7. Harhangi, B.S.; Kompanje, E.J.O.; Leebeek, F.; Maas, A.I. Coagulation disorders after traumatic brain injury. Acta Neurochir. 2008, 150, 165-175. [CrossRef] [PubMed]

8. Auer, L. Disturbances of the coagulatory system in patients with severe cerebral trauma I. Acta Neurochir. 1978, 43, 51-59. [CrossRef]

9. Auer, L.; Ott, E. Disturbances of the coagulatory system in patients with severe cerebral trauma II. Acta Neurochir. 1979, 49, 219-226. [CrossRef]

10. Cortiana, M.; Zagara, G.; Fava, S.; Seveso, M. Coagulation abnormalities in patients with head injury. J. Neurosurg. Sci. 1986, 30, 133-138.

11. Hoyt, D.B. A clinical review of bleeding dilemmas in trauma. Semin. Hematol. 2004, 41, 40-43. [CrossRef] [PubMed]

12. Brohi, K.; Singh, J.; Heron, M.; Coats, T. Acute traumatic coagulopathy. J. Trauma Acute Care Surg. 2003, 54, 1127-1130. [CrossRef] [PubMed]

13. Carrick, M.M.; Tyroch, A.H.; Youens, C.A.; Handley, T. Subsequent development of thrombocytopenia and coagulopathy in moderate and severe head injury: Support for serial laboratory examination. J. Trauma Acute Care Surg. 2005, 58, 725-730. [CrossRef] [PubMed]

14. Hulka, F.; Mullins, R.J.; Frank, E.H. Blunt brain injury activates the coagulation process. Arch. Surg. 1996, 131, 923-928. [CrossRef] [PubMed]

15. Hymel, K.P.; Abshire, T.C.; Luckey, D.W.; Jenny, C. Coagulopathy in pediatric abusive head trauma. Pediatrics 1997, 99, 371-375. [CrossRef] [PubMed]

16. Keller, M.S.; Fendya, D.G.; Weber, T.R. Glasgow Coma Scale predicts coagulopathy in pediatric trauma patients. Semin. Pediatr. Surg. 2001, 10, 12-16. [CrossRef] [PubMed]

17. Kumura, E.; Sato, M.; Fukuda, A.; Takemoto, Y.; Tanaka, S.; Kohama, A. Coagulation disorders following acute head injury. Acta Neurochir. 1987, 85, 23-28. [CrossRef] [PubMed]

18. Kuo, J.-R.; Chou, T.-J.; Chio, C.-C. Coagulopathy as a parameter to predict the outcome in head injury patients-analysis of 61 cases. J. Clin. Neurosci. 2004, 11, 710-714. [CrossRef] [PubMed]

19. Miner, M.E.; Kaufman, H.H.; Graham, S.H.; Haar, F.H.; Gildenberg, P.L. Disseminated intravascular coagulation fibrinolytic syndrome following head injury in children: Frequency and prognostic implications. J. Pediatr. 1982, 100, 687-691. [CrossRef]

20. Olson, J.D.; Kaufman, H.H.; Moake, J.; O'Gorman, T.W.; Hoots, K.; Wagner, K.; Brown, K.C.; Gildenberg, P.L. The incidence and significance of hemostatic abnormalities in patients with head injuries. Neurosurgery 1989, 24, 825-832. [CrossRef] [PubMed]

21. Pondaag, W. Disseminated intravascular coagulation related to outcome in head injury. Acta Neurochir. Suppl. 1979, 28, 98-102. [PubMed]

22. Selladurai, B.M.; Vickneswaran, M.; Duraisamy, S.; Atan, M. Coagulopathy in acute head injury-a study of its role as a prognostic indicator. Br. J. Neurosurg. 1997, 11, 398-404. [CrossRef]

23. Maegele, M.; Schöchl, H.; Menovsky, T.; Maréchal, H.; Marklund, N.; Buki, A.; Stanworth, S. Coagulopathy and haemorrhagic progression in traumatic brain injury: Advances in mechanisms, diagnosis, and management. Lancet Neurol. 2017, 16, 630-647. [CrossRef]

24. Shehata, M.; Afify, M.I.; El-Shafie, M.; Khaled, M. Prevalence and Clinical Implications of Coagulopathy in Patients with Isolated Head Traum. Med. J. Cairo Univ. 2011, 79, 131-137.

25. Chhabra, G.; Rangarajan, K.; Subramanian, A.; Agrawal, D.; Sharma, S.; Mukhopadhayay, A. Hypofibrinogenemia in isolated traumatic brain injury in Indian patients. Neurol. India 2010, 58, 756-757.

26. Epstein, D.S.; Mitra, B.; O’Reilly, G.; Rosenfeld, J.V.; Cameron, P.A. Acute traumatic coagulopathy in the setting of isolated traumatic brain injury: A systematic review and meta-analysis. Injury 2014, 45, 819-824. [CrossRef] [PubMed]

27. Zehtabchi, S.; Baki, S.G.A.; Falzon, L.; Nishijima, D.K. Tranexamic acid for traumatic brain injury: A systematic review and meta-analysis. Am. J. Emerg. Med. 2014, 32, 1503-1509. [CrossRef] [PubMed]

28. Talving, P.; Benfield, R.; Hadjizacharia, P.; Inaba, K.; Chan, L.S.; Demetriades, D. Coagulopathy in severe traumatic brain injury: A prospective study. J. Trauma Acute Care Surg. 2009, 66, 55-62. [CrossRef] [PubMed]

29. Lustenberger, T.; Talving, P.; Kobayashi, L.; Barmparas, G.; Inaba, K.; Lam, L.; Branco, B.C.; Demetriades, D. Early coagulopathy after isolated severe traumatic brain injury: Relationship with hypoperfusion challenged. J. Trauma 2010, 69, 1410-1414. [CrossRef] 
30. Lustenberger, T.; Talving, P.; Kobayashi, L.; Inaba, K.; Lam, L.; Plurad, D.; Demetriades, D. Time course of coagulopathy in isolated severe traumatic brain injury. Injury 2010, 41, 924-928. [CrossRef] [PubMed]

31. Wafaisade, A.; Lefering, R.; Tjardes, T.; Wutzler, S.; Simanski, C.; Paffrath, T.; Fischer, P.; Bouillon, B.; Maegele, M.; Trauma Registry of DGU. Acute coagulopathy in isolated blunt traumatic brain injury. Neurocrit. Care 2010, 12, 211-219. [CrossRef] [PubMed]

32. Greuters, S.; van den Berg, A.; Franschman, G.; Viersen, V.A.; Beishuizen, A.; Peerdeman, S.M.; Boer, C. Acute and delayed mild coagulopathy are related to outcome in patients with isolated traumatic brain injury. Crit. Care 2011, 15, R2. [CrossRef] [PubMed]

33. Franschman, G.; Greuters, S.; Jansen, W.H.; Posthuma, L.M.; Peerdeman, S.M.; Wattjes, M.P.; Loer, S.A.; Boer, C. Haemostatic and cranial computed tomography characteristics in patients with acute and delayed coagulopathy after isolated traumatic brain injury. Brain Inj. 2012, 26, 1464-1471. [CrossRef] [PubMed]

34. Genét, G.F.; Johansson, P.I.; Meyer, M.A.S.; Sølbeck, S.; Sørensen, A.M.; Larsen, C.F.; Welling, K.L.; Windeløv, N.A.; Rasmussen, L.S.; Ostrowski, S.R. Trauma-induced coagulopathy: Standard coagulation tests, biomarkers of coagulopathy, and endothelial damage in patients with traumatic brain injury. J. Neurotrauma 2013, 30, 301-306. [CrossRef]

35. Alexiou, G.A.; Lianos, G.; Fotakopoulos, G.; Michos, E.; Pachatouridis, D.; Voulgaris, S. Admission glucose and coagulopathy occurrence in patients with traumatic brain injury. Brain Inj. 2014, 28, 438-441. [CrossRef] [PubMed]

36. Joseph, B.; Aziz, H.; Zangbar, B.; Kulvatunyou, N.; Pandit, V.; O’Keeffe, T.; Tang, A.; Wynne, J.; Friese, R.S.; Rhee, P. Acquired coagulopathy of traumatic brain injury defined by routine laboratory tests: Which laboratory values matter? J. Trauma Acute Care Surg. 2014, 76, 121-125. [CrossRef]

37. de Oliveira Manoel, A.L.; Neto, A.C.; Veigas, P.V.; Rizoli, S. Traumatic brain injury associated coagulopathy. Neurocrit. Care 2015, 22, 34-44. [CrossRef]

38. Dekker, S.E.; Duvekot, A.; de Vries, H.-M.; Geeraedts, L.M., Jr.; Peerdeman, S.M.; de Waard, M.C.; Boer, C.; Schober, P. Relationship between tissue perfusion and coagulopathy in traumatic brain injury. J. Surg. Res. 2016, 205, 147-154. [CrossRef]

39. Dragan, B.; Adamik, B.; Burzynska, M.; Dragan, S.L.; Gozdzik, W. Platelet Receptor Activity for Predicting Survival in Patients with Intracranial Bleeding. J. Clin. Med. 2021, 10, 2205. [CrossRef]

40. Fletcher-Sandersjöö, A.; Thelin, E.P.; Maegele, M.; Svensson, M.; Bellander, B.-M. Time course of hemostatic disruptions after traumatic brain injury: A systematic review of the literature. Neurocrit. Care 2021, 34, 635-656. [CrossRef]

41. Yuan, Q.; Yu, J.; Wu, X.; Sun, Y.-r.; Li, Z.-q.; Du, Z.-y.; Wu, X.-h.; Hu, J. Prognostic value of coagulation tests for in-hospital mortality in patients with traumatic brain injury. Scand. J. Trauma Resusc. Emerg. Med. 2018, 26, 3. [CrossRef] [PubMed]

42. Gratz, J.; Güting, H.; Thorn, S.; Brazinova, A.; Görlinger, K.; Schäfer, N.; Schöchl, H.; Stanworth, S.; Maegele, M. Protocolised thromboelastometric-guided haemostatic management in patients with traumatic brain injury: A pilot study. Anaesthesia 2019, 74, 883-890. [CrossRef] [PubMed]

43. Schochl, H.; Voelckel, W.; Grassetto, A.; Schlimp, C.J. Practical application of point-of-care coagulation testing to guide treatment decisions in trauma. J. Trauma Acute Care Surg. 2013, 74, 1587-1598. [CrossRef] [PubMed]

44. Hartmann, J.; Walsh, M.; Grisoli, A.; Thomas, A.V.; Shariff, F.; McCauley, R.; Lune, S.V.; Zackariya, N.; Patel, S.; Farrell, M.S.; et al. Diagnosis and Treatment of Trauma-Induced Coagulopathy by Viscoelastography. Semin. Thromb. Hemost. 2020, 46, 134-146. [CrossRef] [PubMed]

45. Rimaitis, M.; Bilskienè, D.; Tamošuitis, T.; Vilcinis, R.; Rimaitis, K.; Macas, A. Implementation of Thromboelastometry for Coagulation Management in Isolated Traumatic Brain Injury Patients Undergoing Craniotomy. Med. Sci. Monit. 2020, 26, e922879. [CrossRef] [PubMed]

46. Rossaint, R.; Bouillon, B.; Cerny, V.; Coats, T.J.; Duranteau, J.; Fernandez-Mondejar, E.; Filipescu, D.; Hunt, B.J.; Komadina, R.; Nardi, G.; et al. The European guideline on management of major bleeding and coagulopathy following trauma: Fourth edition. Crit. Care 2016, 20, 100. [CrossRef] [PubMed]

47. Spahn, D.R.; Bouillon, B.; Cerny, V.; Duranteau, J.; Filipescu, D.; Hunt, B.J.; Komadina, R.; Maegele, M.; Nardi, G.; Riddez, L. The European guideline on management of major bleeding and coagulopathy following trauma: Fifth edition. Crit. Care 2019, $23,98$. [CrossRef]

48. Maegele, M.; Aversa, J.; Marsee, M.K.; McCauley, R.; Chitta, S.H.; Vyakaranam, S.; Walsh, M. Changes in coagulation following brain injury. Semin. Thromb. Hemost. 2020, 46, 155-166. [CrossRef]

49. Thorn, S.; Güting, H.; Mathes, T.; Schäfer, N.; Maegele, M. The effect of platelet transfusion in patients with traumatic brain injury and concomitant antiplatelet use: A systematic review and meta-analysis. Transfusion 2019, 59, 3536-3544. [CrossRef]

50. Böhm, J.K.; Güting, H.; Thorn, S.; Schäfer, N.; Rambach, V.; Schöchl, H.; Grottke, O.; Rossaint, R.; Stanworth, S.; Curry, N. Global characterisation of coagulopathy in isolated traumatic brain injury (iTBI): A CENTER-TBI analysis. Neurocrit. Care 2021, 35, 184-196. [CrossRef]

51. Cap, A.P.; Spinella, P.C. Severity of head injury is associated with increased risk of coagulopathy in combat casualties. J. Trauma Acute Care Surg. 2011, 71, S78-S81. [CrossRef] [PubMed]

52. Herbert, J.P.; Guillotte, A.R.; Hammer, R.D.; Litofsky, N.S. Coagulopathy in the setting of mild traumatic brain injury: Truths and consequences. Brain Sci. 2017, 7, 92. [CrossRef]

53. Castellino, F.J.; Chapman, M.P.; Donahue, D.L.; Thomas, S.; Moore, E.E.; Wohlauer, M.V.; Fritz, B.; Yount, R.; Ploplis, V.; Davis, P.; et al. Traumatic brain injury causes platelet adenosine diphosphate and arachidonic acid receptor inhibition independent of hemorrhagic shock in humans and rats. J. Trauma Acute Care Surg. 2014, 76, 1169-1176. [CrossRef] [PubMed] 
54. Salehpour, F.; Bazzazi, A.M.; Porhomayon, J.; Nader, N.D. Correlation between coagulopathy and outcome in severe head trauma in neurointensive care and trauma units. J. Crit. Care 2011, 26, 352-356. [CrossRef] [PubMed]

55. Maegele, M.; Lefering, R.; Yucel, N.; Tjardes, T.; Rixen, D.; Paffrath, T. Early Coagulopathy in mulitple injury: An analysis from the German Trauma Registry on 8724 patients. Injury 2007, 38, 298-304. [CrossRef]

56. Sixta, S.L.; Cardenas, J.C.; Kitagawa, R.; Wade, C.E.; Holcomb, J.B.; Cotton, B.A. Hypocoagulability in traumatic brain injury as measured by traditional means and thrombelastography. J. Neurol. Neurophysiol. 2015, 6, 1-5.

57. Thorn, S.; Lefering, R.; Maegele, M.; Gruen, R.L.; Mitra, B. Early prediction of acute traumatic coagulopathy: A validation of the COAST score using the German Trauma Registry. Eur. J. Trauma Emerg. Surg. 2019, 47, 333-341. [CrossRef]

58. Cannon, J.W.D.; Dias, J.D.; Kumar, M.A.; Walsh, M.; Thomas, S.; Cotton, B.A.; Schuster, J.; Evans, S.; Schreiber, M.A.; Adam, E.; et al. Use of Thromboelastography in the Evaluation and Management of Patients With Traumatic Brain Injury: A Systematic Review and Meta-Analysis. Crit. Care Explor. 2021, 3, e0526. [CrossRef]

59. Maegele, M. Coagulopathy after traumatic brain injury: Incidence, pathogenesis, and treatment options. Transfusion 2013, 53, 28S-37S. [CrossRef]

60. Samuels, J.M.; Moore, E.E.; Silliman, C.C.; Banerjee, A.; Cohen, M.J.; Ghasabyan, A.; Chandler, J.; Coleman, J.R.; Sauaia, A. Severe traumatic brain injury is associated with a unique coagulopathy phenotype. J. Trauma Acute Care Surg. 2019, 86, 686-693. [CrossRef]

61. Furay, E.; Daley, M.; Teixeira, P.G.; Coopwood, T.B.; Aydelotte, J.D.; Malesa, N.; Tellinghuisen, C.; Ali, S.; Brown, L.H.; Brown, C.V. Goal-directed platelet transfusions correct platelet dysfunction and may improve survival in patients with severe traumatic brain injury. J. Trauma Acute Care Surg. 2018, 85, 881-887. [CrossRef]

62. Furay, E.J.; Daley, M.J.; Satarasinghe, P.; Lara, S.; Aydelotte, J.D.; Teixeira, P.G.; Coopwood, T.B.; Ali, S.; Brown, C.V. Desmopressin is a transfusion sparing option to reverse platelet dysfunction in patients with severe traumatic brain injury. J. Trauma Acute Care Surg. 2020, 88, 80-86. [CrossRef] [PubMed]

63. Riojas, C.M.; Ekaney, M.L.; Ross, S.W.; Cunningham, K.W.; Furay, E.J.; Brown, C.V.; Evans, S.L. Platelet Dysfunction after Traumatic Brain Injury: A Review. J. Neurotrauma 2021, 38, 819-829. [CrossRef]

64. Guillotte, A.R.; Herbert, J.P.; Madsen, R.; Hammer, R.D.; Litofsky, N.S. Effects of platelet dysfunction and platelet transfusion on outcomes in traumatic brain injury patients. Brain Inj. 2018, 32, 1849-1857. [CrossRef]

65. Solomon, C.; Traintinger, S.; Ziegler, B.; Hanke, A.; Rahe-Meyer, N.; Voelckel, W.; Schochl, H. Platelet function following trauma. A multiple electrode aggregometry study. Thromb. Haemost. 2011, 106, 322-330.

66. Briggs, A.; Gates, J.D.; Kaufman, R.M.; Calahan, C.; Gormley, W.B.; Havens, J.M. Platelet dysfunction and platelet transfusion in traumatic brain injury. J. Surg. Res. 2015, 193, 802-806. [CrossRef] [PubMed]

67. Parry, P.V.; Choi, P.A.; Bauer, J.S.; Panczykowski, D.M.; Puccio, A.M.; Okonkwo, D.O. Utility of the aspirin and P2Y12 response assays to determine the effect of antiplatelet agents on platelet reactivity in traumatic brain injury. Neurosurgery 2017, 80, 92-96. [CrossRef] [PubMed]

68. Yuan, Q.; Sun, Y.-R.; Wu, X.; Yu, J.; Li, Z.-Q.; Du, Z.-Y.; Wu, X.-H.; Zhou, L.-F.; Hu, J. Coagulopathy in traumatic brain injury and its correlation with progressive hemorrhagic injury: A systematic review and meta-analysis. J. Neurotrauma 2016, 33, 1279-1291. [CrossRef] [PubMed]

69. Neerman-Arbez, M.; de Moerloose, P.; Casini, A. Laboratory and Genetic Investigation of Mutations Accounting for Congenital Fibrinogen Disorders. Semin. Thromb. Hemost. 2016, 42, 356-365. [PubMed]

70. Can, M.M.; Tanboğa, I.H.; Türkyilmaz, E.; Karabay, C.Y.; Akgun, T.; Koca, F.; Tokgoz, H.C.; Keles, N.; Ozkan, A.; Bezgin, T.; et al. The risk of false results in the assessment of platelet function in the absence of antiplatelet medication: Comparison of the PFA-100, multiplate electrical impedance aggregometry and verify now assays. Thromb. Res. 2010, 125, e132-e137. [CrossRef]

71. Ma, L.; Chen, W.; Pan, Y.; Yan, H.; Li, H.; Meng, X.; Wang, Y.; Wang, Y. Comparison of VerifyNow, thromboelastography, and PL-12 in patients with minor ischemic stroke or transient ischemic attack. Aging 2021, 13, 8396-8407. [CrossRef]

72. Connelly, C.R.; Yonge, J.D.; McCully, S.P.; Hart, K.D.; Hilliard, T.C.; Lape, D.E.; Watson, J.J.; Rick, B.; Houser, B.; Deloughery, T.G. Assessment of three point-of-care platelet function assays in adult trauma patients. J. Surg. Res. 2017, 212, 260-269. [CrossRef] [PubMed]

73. Dias, J.D.; Pottgiesser, T.; Hartmann, J.; Duerschmied, D.; Bode, C.; Achneck, H.E. Comparison of three common whole blood platelet function tests for in vitro P2Y12 induced platelet inhibition. J. Thromb. Thrombolysis 2020, 50, 135-143. [CrossRef] [PubMed]

74. Bachelani, A.M.; Bautz, J.T.; Sperry, J.L.; Corcos, A.; Zenati, M.; Billiar, T.R.; Peitzman, A.B.; Marshall, G.T. Assessment of platelet transfusion for reversal of aspirin after traumatic brain injury. Surgery 2011, 150, 836-843. [CrossRef] [PubMed]

75. Curry, N.S.; Davenport, R.; Pavord, S.; Mallett, S.V.; Kitchen, D.; Klein, A.A.; Maybury, H.; Collins, P.W.; Laffan, M. The use of viscoelastic haemostatic assays in the management of major bleeding: A British Society for Haematology Guideline. Br. J. Haematol. 2018, 182, 789-806. [CrossRef] [PubMed]

76. Wikkelsø, A.; Wetterslev, J.; Møller, A.M.; Afshari, A. Thromboelastography (TEG) or thromboelastometry (ROTEM) to monitor haemostatic treatment versus usual care in adults or children with bleeding. Cochrane Database Syst. Rev. 2016, 2016, CD007871. [CrossRef] [PubMed] 
77. Davenport, R.; Manson, J.; De'Ath, H.; Platton, S.; Coates, A.; Allard, S.; Hart, D.; Pearse, R.; Pasi, K.J.; MacCallum, P.; et al. Functional definition and characterization of acute traumatic coagulopathy. Crit. Care Med. 2011, 39, 2652-2658. [CrossRef] [PubMed]

78. Inaba, K.; Rizoli, S.; Veigas, P.V.; Callum, J.; Davenport, R.; Hess, J.; Maegele, M. 2014 Consensus conference on viscoelastic test-based transfusion guidelines for early trauma resuscitation: Report of the panel. J. Trauma Acute Care Surg. 2015, 78, 1220-1229. [CrossRef] [PubMed]

79. Moore, H.B.; Moore, E.E.; Neal, M.D. Trauma Induced Coagulopathy, 2nd ed.; Spring Nature Switzerland AG: Cham, Switzerland, 2021.

80. Johansson, P.I.; Stensballe, J.; Oliveri, R.; Wade, C.E.; Ostrowski, S.R.; Holcomb, J.B. How I treat patients with massive hemorrhage. Blood 2014, 124, 3052-3058. [CrossRef] [PubMed]

81. Maegele, M. The diagnosis and treatment of acute traumatic bleeding and coagulopathy. Dtsch. Aerzteblatt Int. 2019, 116, 799. [CrossRef] [PubMed]

82. Webb, A.J.; Brown, C.S.; Naylor, R.M.; Rabinstein, A.A.; Mara, K.C.; Nei, A.M. Thromboelastography is a Marker for Clinically Significant Progressive Hemorrhagic Injury in Severe Traumatic Brain Injury. Neurocrit. Care 2021. [CrossRef]

83. Wohlauer, M.V.; Moore, E.E.; Thomas, S.; Sauaia, A.; Evans, E.; Harr, J.; Silliman, C.C.; Ploplis, V.; Castellino, F.J.; Walsh, M. Early platelet dysfunction: An unrecognized role in the acute coagulopathy of trauma. J. Am. Coll. Surg. 2012, 214, 739-746. [CrossRef] [PubMed]

84. Nekludov, M.; Bellander, B.-M.; Blombäck, M.; Wallen, H.N. Platelet dysfunction in patients with severe traumatic brain injury. J. Neurotrauma 2007, 24, 1699-1706. [CrossRef] [PubMed]

85. Jacoby, R.C.; Owings, J.T.; Holmes, J.; Battistella, F.D.; Gosselin, R.C.; Paglieroni, T.G. Platelet activation and function after trauma. J. Trauma 2001, 51, 639-647. [CrossRef]

86. Windelv, N.A.; Welling, K.-L.; Ostrowski, S.R.; Johansson, P.I. The prognostic value of thrombelastography in identifying neurosurgical patients with worse prognosis. Blood Coagul. Fibrinolysis 2011, 22, 416-419. [CrossRef] [PubMed]

87. Kutcher, M.E.; Redick, B.J.; McCreery, R.C.; Crane, I.M.; Greenberg, M.D.; Cachola, L.M.; Nelson, M.F.; Cohen, M.J. Characterization of platelet dysfunction after trauma. J. Trauma Acute Care Surg. 2012, 73, 13-19. [CrossRef]

88. Xu, X.; Kozar, R.; Zhang, J.; Dong, J.F. Diverse activities of von Willebrand factor in traumatic brain injury and associated coagulopathy. J. Thromb. Haemost. 2020, 18, 3154-3162. [CrossRef] [PubMed]

89. Wu, Y.; Liu, W.; Zhou, Y.; Hilton, T.; Zhao, Z.; Liu, W.; Wang, M.; Yeon, J.; Houck, K.; Thiagarajan, P. von Willebrand factor enhances microvesicle-induced vascular leakage and coagulopathy in mice with traumatic brain injury. Blood J. Am. Soc. Hematol. 2018, 132, 1075-1084. [CrossRef]

90. Kurland, D.; Hong, C.; Aarabi, B.; Gerzanich, V.; Simard, J.M. Hemorrhagic progression of a contusion after traumatic brain injury: A review. J. Neurotrauma 2012, 29, 19-31. [CrossRef]

91. Simard, J.M.; Kilbourne, M.; Tsymbalyuk, O.; Tosun, C.; Caridi, J.; Ivanova, S.; Keledjian, K.; Bochicchio, G.; Gerzanich, V. Key role of sulfonylurea receptor 1 in progressive secondary hemorrhage after brain contusion. J. Neurotrauma 2009, 26, 2257-2267. [CrossRef]

92. Di Battista, A.P.; Rizoli, S.B.; Lejnieks, B.; Min, A.; Shiu, M.Y.; Peng, H.T.; Baker, A.J.; Hutchison, M.G.; Churchill, N.; Inaba, K.; et al. Sympathoadrenal activation is associated with acute traumatic coagulopathy and endotheliopathy in isolated brain injury. Shock 2016, 46, 96. [CrossRef] [PubMed]

93. Foley, J.H.; Conway, E.M. Cross talk pathways between coagulation and inflammation. Circ. Res. 2016, 118, 1392-1408. [CrossRef] [PubMed]

94. Nekludov, M.; Mobarrez, F.; Gryth, D.; Bellander, B.-M.; Wallen, H. Formation of microparticles in the injured brain of patients with severe isolated traumatic brain injury. J. Neurotrauma 2014, 31, 1927-1933. [CrossRef]

95. Medcalf, R.L. The traumatic side of fibrinolysis. Blood J. Am. Soc. Hematol. 2015, 125, 2457-2458. [CrossRef] [PubMed]

96. Fletcher-Sandersjöö, A.; Maegele, M.; Bellander, B.-M. Does complement-mediated hemostatic disturbance occur in traumatic brain injury? A literature review and observational study protocol. Int. J. Mol. Sci. 2020, 21, 1596. [CrossRef]

97. Laroche, M.; Kutcher, M.E.; Huang, M.C.; Cohen, M.J.; Manley, G.T. Coagulopathy after traumatic brain injury. Neurosurgery 2012, 70, 1334-1345. [CrossRef] [PubMed]

98. Hijazi, N.; Abu Fanne, R.; Abramovitch, R.; Yarovoi, S.; Higazi, M.; Abdeen, S.; Basheer, M.; Maraga, E.; Cines, D.B.; Al-Roof Higazi, A. Endogenous plasminogen activators mediate progressive intracerebral hemorrhage after traumatic brain injury in mice. Blood 2015, 125, 2558-2567. [CrossRef] [PubMed]

99. Tian, H.-L.; Chen, H.; Wu, B.-S.; Cao, H.-L.; Xu, T.; Hu, J.; Wang, G.; Gao, W.-W.; Lin, Z.-K.; Chen, S.-W. D-dimer as a predictor of progressive hemorrhagic injury in patients with traumatic brain injury: Analysis of 194 cases. Neurosurg. Rev. 2010, 33, 359-366. [CrossRef]

100. Hoffman, M.; Monroe, D.M. Tissue factor in brain is not saturated with factor VIIa: Implications for factor VIIa dosing in intracerebral hemorrhage. Stroke 2009, 40, 2882-2884. [CrossRef]

101. CRASH-3 Trial Collaborators. Effects of tranexamic acid on death, disability, vascular occlusive events and other morbidities in patients with acute traumatic brain injury (CRASH-3): A randomised, placebo-controlled trial. Lancet 2019, 394, 1713-1723. [CrossRef] 
102. Rowell, S.E.; Meier, E.N.; McKnight, B.; Kannas, D.; May, S.; Sheehan, K.; Bulger, E.M.; Idris, A.H.; Christenson, J.; Morrison, L.J.; et al. Effect of Out-of-Hospital Tranexamic Acid vs Placebo on 6-Month Functional Neurologic Outcomes in Patients with Moderate or Severe Traumatic Brain Injury. JAMA 2020, 324, 961-974. [CrossRef]

103. Cotton, B.A.; Harvin, J.A.; Kostousouv, V.; Minei, K.M.; Radwan, Z.A.; Schöchl, H.; Wade, C.E.; Holcomb, J.B.; Matijevic, N. Hyperfibrinolysis at admission is an uncommon but highly lethal event associated with shock and prehospital fluid administration. J. Trauma Acute Care Surg. 2012, 73, 365-370. [CrossRef] [PubMed]

104. Moore, H.B.; Moore, E.E.; Liras, I.N.; Gonzalez, E.; Harvin, J.A.; Holcomb, J.B.; Sauaia, A.; Cotton, B.A. Acute fibrinolysis shutdown after injury occurs frequently and increases mortality: A multicenter evaluation of 2540 severely injured patients. $J$. Am. Coll. Surg. 2016, 222, 347-355. [CrossRef] [PubMed]

105. Johansson, P.I.; Stissing, T.; Bochsen, L.; Ostrowski, S.R. Thrombelastography and tromboelastometry in assessing coagulopathy in trauma. Scand J. Trauma Resusc. Emerg. Med. 2009, 17, 45. [CrossRef] [PubMed]

106. Kashuk, J.L.; Moore, E.E.; Sawyer, M.; Le, T.; Johnson, J.; Biffl, W.L.; Cothren, C.C.; Barnett, C.; Stahel, P.; Sillman, C.C.; et al. Postinjury coagulopathy management: Goal directed resuscitation via POC thrombelastography. Ann. Surg. 2010, 251, 604-614. [CrossRef]

107. Gonzalez, E.; Pieracci, F.M.; Moore, E.E.; Kashuk, J.L. Coagulation abnormalities in the trauma patient: The role of point-of-care thromboelastography. Semin. Thromb. Hemost. 2010, 36, 723-737. [CrossRef]

108. MacDonald, S.G.; Luddington, R.J. Critical factors contributing to the thromboelastography trace. Semin. Thromb. Hemost. 2010, 36, 712-722. [CrossRef]

109. Bochsen, L.; Wiinberg, B.; Kjelgaard-Hansen, M.; Steinbruchel, D.A.; Johansson, P.I. Evaluation of the TEG platelet mapping assay in blood donors. Thromb. J. 2007, 5, 3. [CrossRef] [PubMed]

110. Bartels, A.N.; Johnson, C.; Lewis, J.; Clevenger, J.W.; Barnes, S.L.; Hammer, R.D.; Ahmad, S. Platelet adenosine diphosphate inhibition in trauma patients by thromboelastography correlates with paradoxical increase in platelet dense granule content by flow cytometry. Surgery 2016, 160, 954-959. [CrossRef] [PubMed]

111. Solomon, C.; Schöchl, H.; Ranucci, M.; Schlimp, C. Can the Viscoelastic Parameter $\alpha$-Angle Distinguish Fibrinogen from Platelet Deficiency and Guide Fibrinogen Supplementation? Anesth. Analg. 2015, 121, 289-301. [CrossRef] [PubMed]

112. Walsh, M.; Jbara, M.; Miller, A.; Lawson, J. Thromboelastographic Guided Blood Component Therapy for Severe Hemorrhage. In Blood Bulletin; Gresens, C., Ed.; America's Blood Centers: Washington, DC, USA, 2014.

113. Ranucci, M.; Baryshnikova, E. Sensitivity of viscoelastic tests to platelet function. J. Clin. Med. 2020, 9, 189. [CrossRef]

114. Sayce, A.C.; Neal, M.D.; Leeper, C.M. Viscoelastic monitoring in trauma resuscitation. Transfusion 2020, 60, S33-S51. [CrossRef]

115. Toffaletti, J.G.; Buckner, K.A. Use of Earlier-Reported Rotational Thromboelastometry Parameters to Evaluate Clotting Status, Fibrinogen, and Platelet Activities in Postpartum Hemorrhage Compared to Surgery and Intensive Care Patients. Anesth. Analg. 2019, 128, 414-423. [CrossRef]

116. Görlinger, K.; Pérez-Ferrer, A.; Dirkmann, D.; Saner, F.; Maegele, M.; Calatayud, Á.A.P.; Kim, T.-Y. The role of evidence-based algorithms for rotational thromboelastometry-guided bleeding management. Korean J. Anesthesiol. 2019, 72, 297. [CrossRef] [PubMed]

117. Kornblith, L.Z.; Moore, H.B.; Cohen, M.J. Trauma-induced coagulopathy: The past, present, and future. J. Thromb. Haemost. 2019, 17, 852-862. [CrossRef]

118. Darlington, D.N.; Wu, X.; Keesee, J.D.; Cap, A.P. Severe trauma and hemorrhage leads to platelet dysfunction and changes in cyclic nucleotides in the rat. Shock 2020, 53, 468-475. [CrossRef]

119. Tóth, O.; Calatzis, A.; Penz, S.; Losonczy, H.; Siess, W. Multiple electrode aggregometry: A new device to measure platelet aggregation in whole blood. Thromb. Haemost. 2006, 96, 781-788. [PubMed]

120. George, M.J.; Burchfield, J.; MacFarlane, B.; Wang, Y.W.; Cardenas, J.C.; White, N.J.; Gill, B.S.; Wade, C.E. Multiplate and TEG platelet mapping in a population of severely injured trauma patients. Transfus. Med. 2018, 28, 224-230. [CrossRef]

121. Walsh, M.; Fritz, S.; Hake, D.; Son, M.; Greve, S.; Jbara, M.; Chitta, S.; Fritz, B.; Miller, A.; Bader, M.K.; et al. Targeted Thromboelastographic (TEG) Blood Component and Pharmacologic Hemostatic Therapy in Traumatic and Acquired Coagulopathy. Curr. Drug Targets 2016, 17, 954-970. [CrossRef] [PubMed]

122. Roozenbeek, B.; Maas, A.I.; Menon, D.K. Changing patterns in the epidemiology of traumatic brain injury. Nat. Rev. Neurol. 2013, 9, 231-236. [CrossRef] [PubMed]

123. Lindblad, C.; Thelin, E.P.; Nekludov, M.; Frostell, A.; Nelson, D.W.; Svensson, M.; Bellander, B.M. Assessment of Platelet Function in Traumatic Brain Injury-A Retrospective Observational Study in the Neuro-Critical Care Setting. Front. Neurol. 2018, 9, 15. [CrossRef]

124. Nishijima, D.K.; Zehtabchi, S.; Berrong, J.; Legome, E. Utility of platelet transfusion in adult patients with traumatic intracranial hemorrhage and pre-injury anti-platelet use: A systematic review. J. Trauma Acute Care Surg. 2012, 72, 1658. [CrossRef] [PubMed]

125. Anglin, C.O.; Spence, J.S.; Warner, M.A.; Paliotta, C.; Harper, C.; Moore, C.; Sarode, R.; Madden, C.; Diaz-Arrastia, R. Effects of platelet and plasma transfusion on outcome in traumatic brain injury patients with moderate bleeding diatheses. J. Neurosurg. 2013, 118, 676-686. [CrossRef] [PubMed]

126. Baharoglu, M.I.; Cordonnier, C.; Salman, R.A.-S.; De Gans, K.; Koopman, M.M.; Brand, A.; Majoie, C.B.; Beenen, L.F.; Marquering, H.A.; Vermeulen, M. Platelet transfusion versus standard care after acute stroke due to spontaneous cerebral haemorrhage associated with antiplatelet therapy (PATCH): A randomised, open-label, phase 3 trial. Lancet 2016, 387, 2605-2613. [CrossRef] 
127. Dias, J.D.; Lopez-Espina, C.G.; Ippolito, J.; Hsiao, L.H.; Zaman, F.; Muresan, A.A.; Thomas, S.G.; Walsh, M.; Jones, A.J.; Grisoli, A.; et al. Rapid point-of-care detection and classification of direct-acting oral anticoagulants with the TEG 6s: Implications for trauma and acute care surgery. J. Trauma Acute Care Surg. 2019, 87, 364-370. [CrossRef] [PubMed]

128. Scorer, T.G.; FitzGibbon, L.; Aungraheeta, R.; Sharma, U.; Peltier, G.C.; McIntosh, C.S.; Reddoch-Cardenas, K.M.; Meyer, A.; Cap, A.P.; Mumford, A.D. TEG PlateletMapping assay results may be misleading in the presence of cold stored platelets. Transfusion 2020, 60, S119-S123. [CrossRef] [PubMed]

129. Gonzalez, E.; Moore, E.E.; Moore, H.B.; Chapman, M.P.; Chin, T.L.; Ghasabyan, A.; Wohlauer, M.V.; Barnett, C.C.; Bensard, D.D.; Biffl, W.L.; et al. Goal-directed Hemostatic Resuscitation of Trauma-induced Coagulopathy: A Pragmatic Randomized Clinical Trial Comparing a Viscoelastic Assay to Conventional Coagulation Assays. Ann. Surg. 2016, 263, 1051-1059. [CrossRef] [PubMed]

130. Brazinova, A.; Majdan, M.; Leitgeb, J.; Trimmel, H.; Mauritz, W.; Austrian Working Group on Improvement of Early, T.B.I.C. Factors that may improve outcomes of early traumatic brain injury care: Prospective multicenter study in Austria. Scand. J. Trauma Resusc. Emerg. Med. 2015, 23, 53. [CrossRef]

131. Martini, W.Z. Coagulation complications following trauma. Mil. Med. Res. 2016, 3, 35. [CrossRef]

132. Beynon, C.; Wessels, L.; Unterberg, A.W. Point-of-care testing in neurosurgery. Semin. Thromb. Hemost. 2017, 43, 416-422.

133. Chang, R.; Cardenas, J.C.; Wade, C.E.; Holcomb, J.B. Advances in the understanding of trauma-induced coagulopathy. Blood 2016, 128, 1043-1049. [CrossRef]

134. Cap, A.; Hunt, B. The pathogenesis of traumatic coagulopathy. Anaesthesia 2015, 70, 96-101. [CrossRef]

135. Valle, E.J.; Van Haren, R.M.; Allen, C.J.; Jouria, J.M.; Bullock, M.R.; Schulman, C.I.; Namias, N.; Livingstone, A.S.; Proctor, K.G. Does traumatic brain injury increase the risk for venous thromboembolism in polytrauma patients? J. Trauma Acute Care Surg. 2014, 77, 243-250. [CrossRef]

136. Liu, H.; Li, J.; Yu, J.; Yuan, T. Research into the predictive effect of TEG in the changes of coagulation functions of the patients with traumatic brain hemorrhage. Open Med. 2015, 10, 399-404. [CrossRef]

137. Martin, G.; Shah, D.; Elson, N.; Boudreau, R.; Hanseman, D.; Pritts, T.A.; Makley, A.T.; Foreman, B.; Goodman, M.D. Relationship of coagulopathy and platelet dysfunction to transfusion needs after traumatic brain injury. Neurocrit. Care 2018, $28,330-337$. [CrossRef]

138. Dunham, C.M.; Hoffman, D.A.; Huang, G.S.; Omert, L.A.; Gemmel, D.J.; Merrell, R. Traumatic intracranial hemorrhage correlates with preinjury brain atrophy, but not with antithrombotic agent use: A retrospective study. PLoS ONE 2014, 9, e109473. [CrossRef]

139. Folkerson, L.E.; Sloan, D.; Davis, E.; Kitagawa, R.S.; Cotton, B.A.; Holcomb, J.B.; Tomasek, J.S.; Wade, C.E. Coagulopathy as a predictor of mortality after penetrating traumatic brain injury. Am. J. Emerg. Med. 2018, 36, 38-42. [CrossRef]

140. Baksaas-Aasen, K.; Gall, L.S.; Stensballe, J.; Juffermans, N.P.; Curry, N.; Maegele, M.; Brooks, A.; Rourke, C.; Gillespie, S.; Murphy, J. Viscoelastic haemostatic assay augmented protocols for major trauma haemorrhage (ITACTIC): A randomized, controlled trial. Intensive Care Med. 2021, 47, 49-59. [CrossRef]

141. Hota, S.; Ng, M.; Hilliard, D.; Burgess, J. Thromboelastogram-Guided Resuscitation for Patients with Traumatic Brain Injury on Novel Anticoagulants. Am. Surg. 2019, 85, 861-864. [CrossRef]

142. Holzmacher, J.L.; Reynolds, C.; Patel, M.; Maluso, P.; Holland, S.; Gamsky, N.; Moore, H.; Acquista, E.; Carrick, M.; Amdur, R. Platelet transfusion does not improve outcomes in patients with brain injury on antiplatelet therapy. Brain Inj. 2018, 32, 325-330. [CrossRef]

143. Kumar, M.; Ahmad, J.; Maiwall, R.; Choudhury, A.; Bajpai, M.; Mitra, L.G.; Saluja, V.; Mohan Agarwal, P.; Bihari, C.; Shasthry, S.M. Thromboelastography-Guided Blood Component Use in Patients With Cirrhosis With Nonvariceal Bleeding: A Randomized Controlled Trial. Hepatology 2019, 71, 235-246. [CrossRef] [PubMed]

144. Kay, A.B.; Morris, D.S.; Collingridge, D.S.; Majercik, S. Platelet dysfunction on thromboelastogram is associated with severity of blunt traumatic brain injury. Am. J. Surg. 2019, 218, 1134-1137. [CrossRef] [PubMed]

145. Martínez, J.T.; Petrone, P.; Axelrad, A.; Marini, C.P. Comparison between thromboelastography and conventional coagulation test: Should we abandon conventional coagulation tests in polytrauma patients? Cirugía Española 2018, 96, 443-449. [CrossRef]

146. Ologun, G.O.; Pamula, A.; Alegbejo-Olarinoye, M.; Granet, P.; Behm, R. Rethinking the Use of Routine Platelet Transfusions for Head Injured Patients on Antiplatelet Therapy. Cureus 2019, 11, e6136. [CrossRef]

147. Ganter, M.T.; Hofer, C.K. Coagulation monitoring: Current techniques and clinical use of viscoelastic point-of-care coagulation devices. Anesth. Analg. 2008, 106, 1366-1375. [CrossRef]

148. Orban, M.; Sibbing, D. Chapter 10: Multiplate Analyzer. In Antiplatelet Therapy in Cardiovascular Disease; Waksman, R., Gurbel, P.A., Gaglia, M.A., Eds.; John Wiley \& Sons, Inc.: Hoboken, NJ, USA, 2014; pp. 82-91. ISBN 978-1-118-275-757.

149. Bora, S.K.; Sahu, R.N. Extending Horizons of Extracorporeal Membrane Oxygenation: Can the Tight Rope of Anticoagulation Help Further? J. Card. Crit. Care TSS 2018, 2, 049-050. [CrossRef]

150. Stettler, G.R.; Moore, E.E.; Moore, H.B.; Nunns, G.R.; Huebner, B.R.; Einersen, P.; Ghasabyan, A.; Silliman, C.C.; Banerjee, A.; Sauaia, A. Platelet adenosine diphosphate receptor inhibition provides no advantage in predicting need for platelet transfusion or massive transfusion. Surgery 2017, 162, 1286-1294. [CrossRef]

151. Daley, M.; Enright, Z.; Nguyen, J.; Ali, S.; Clark, A.; Aydelotte, J.; Teixeira, P.; Coopwood, T.; Brown, C. Adenosine diphosphate platelet dysfunction on thromboelastogram is independently associated with increased morality in traumatic brain injury. Eur. J. Trauma Emerg. Surg. 2017, 43, 105-111. [CrossRef] [PubMed] 
152. Rao, A.; Lin, A.; Hilliard, C.; Fu, R.; Lennox, T.; Barbosa, R.; Schreiber, M.; Rowell, S. The utility of thromboelastography for predicting the risk of progression of intracranial hemorrhage in traumatic brain injury patients. Neurosurgery 2017, 64, 182-187. [CrossRef]

153. Folkerson, L.E.; Sloan, D.; Cotton, B.A.; Holcomb, J.B.; Tomasek, J.S.; Wade, C.E. Predicting progressive hemorrhagic injury from isolated traumatic brain injury and coagulation. Surgery 2015, 158, 655-661. [CrossRef]

154. Holcomb, J.B.; Minei, K.M.; Scerbo, M.L.; Radwan, Z.A.; Wade, C.E.; Kozar, R.A.; Gill, B.S.; Albarado, R.; McNutt, M.K.; Khan, S. Admission rapid thrombelastography can replace conventional coagulation tests in the emergency department: Experience with 1974 consecutive trauma patients. Ann. Surg. 2012, 256, 476-486. [CrossRef]

155. Tapia, N.; Chang, A.; Norman, M.; Welsh, F.; Scott, B.; Wall, M.; Mattox, K.; Suliburk, J. TEG-guided resuscitation is superior to standardized MTP resuscitation in massively transfused penetrating trauma patients. J. Trauma Acute Care Surg. 2013, 74, 378-386. [CrossRef]

156. Plotkin, A.J.; Wade, C.E.; Jenkins, D.H.; Smith, K.A.; Noe, J.C.; Park, M.S.; Perkins, J.G.; Holcomb, J.B. A reduction in clot formation rate and strength assessed by thrombelastography is indicative of transfusion requirements in patients with penetrating injuries. J. Trauma 2008, 64, S64-S68. [CrossRef]

157. Kaufmann, C.R.; Dwyer, K.M.; Crews, J.D.; Dols, S.J.; Trask, A.L. Usefulness of thrombelastography in assessment of trauma patient coagulation. J. Trauma 1997, 42, 716-720, discussion 720-712. [CrossRef]

158. Spahn, D.R.; Bouillon, B.; Cerny, V.; Coats, T.J.; Duranteau, J.; Fernández-Mondéjar, E.; Filipescu, D.; Hunt, B.J.; Komadina, R.; Nardi, G. Management of bleeding and coagulopathy following major trauma: An updated European guideline. Crit. Care 2013, 17, R76. [CrossRef] [PubMed]

159. Curry, N.S.; Davenport, R. Transfusion strategies for major haemorrhage in trauma. Br. J. Haematol. 2019, 184, 508-523. [CrossRef] [PubMed]

160. Cryer, H.G.; Nathens, A.B.; Bulger, E.M.; Calland, J.F.; Cohen, M.J.; Cotton, B.A.; Davis, M.L.; Hemmila, M.R.; Hess, J.R.; Jawa, R.; et al. Massive Transfusion in Trauma Guidelines; American College of Surgeons: Chicago, IL, USA, 2013.

161. Gruen, D.S.; Guyette, F.X.; Brown, J.B.; Okonkwo, D.O.; Puccio, A.M.; Campwala, I.K.; Tessmer, M.T.; Daley, B.J.; Miller, R.S.; Harbrecht, B.G. Association of prehospital plasma with survival in patients with traumatic brain injury: A secondary analysis of the PAMPer cluster randomized clinical trial. JAMA Netw. Open 2020, 3, e2016869. [CrossRef]

162. Sperry, J.L.; Guyette, F.X.; Brown, J.B.; Yazer, M.H.; Triulzi, D.J.; Early-Young, B.J.; Adams, P.W.; Daley, B.J.; Miller, R.S.; Harbrecht, B.G. Prehospital plasma during air medical transport in trauma patients at risk for hemorrhagic shock. N. Engl. J. Med. 2018, 379, 315-326. [CrossRef] [PubMed]

163. Chang, R.; Holcomb, J.B. Optimal fluid therapy for traumatic hemorrhagic shock. Crit. Care Clin. 2017, 33, 15-36. [CrossRef]

164. Etemadrezaie, H.; Baharvahdat, H.; Shariati, Z.; Lari, S.M.; Shakeri, M.T.; Ganjeifar, B. The effect of fresh frozen plasma in severe closed head injury. Clin. Neurol. Neurosurg. 2007, 109, 166-171. [CrossRef] [PubMed]

165. Jokar, T.O.; Khalil, M.; Rhee, P.; Kulvatunyou, N.; Pandit, V.; O'Keeffe, T.; Tang, A.; Joseph, B. Ratio-based resuscitation in trauma patients with traumatic brain injury: Is there a similar effect? Am. Surg. 2016, 82, 271-277. [CrossRef] [PubMed]

166. Walsh, M.; Moore, E.E.; Moore, H.B.; Thomas, S.; Kwaan, H.C.; Speybroeck, J.; Marsee, M.; Bunch, C.M.; Stillson, J.; Thomas, A.V.; et al. Whole Blood, Fixed Ratio, or Goal-Directed Blood Component Therapy for the Initial Resuscitation of Severely Hemorrhaging Trauma Patients: A Narrative Review. J. Clin. Med. 2021, 10, 320. [CrossRef] [PubMed]

167. Simurda, T.; Casini, A.; Stasko, J.; Hudecek, J.; Skornova, I.; Vilar, R.; Neerman-Arbez, M.; Kubisz, P. Perioperative management of a severe congenital hypofibrinogenemia with thrombotic phenotype. Thromb. Res. 2020, 188, 1-4. [CrossRef] [PubMed]

168. Simurda, T.; Caccia, S.; Asselta, R.; Zolkova, J.; Stasko, J.; Skornova, I.; Snahnicanova, Z.; Loderer, D.; Lasabova, Z.; Kubisz, P. Congenital hypofibrinogenemia associated with a novel heterozygous nonsense mutation in the globular C-terminal domain of the $\gamma$-chain (p.Glu275Stop). J. Thromb. Thrombolysis 2020, 50, 233-236. [CrossRef] [PubMed]

169. Pahatouridis, D.; Alexiou, G.A.; Zigouris, A.; Mihos, E.; Drosos, D.; Voulgaris, S. Coagulopathy in moderate head injury. The role of early administration of low molecular weight heparin. Brain Inj. 2010, 24, 1189-1192. [CrossRef] [PubMed]

170. Rourke, C.; Curry, N.; Khan, S.; Taylor, R.; Raza, I.; Davenport, R.; Stanworth, S.; Brohi, K. Fibrinogen levels during trauma hemorrhage, response to replacement therapy, and association with patient outcomes. J. Thromb. Haemost. 2012, 10, 1342-1351. [CrossRef] [PubMed]

171. Muradashvili, N.; Lominadze, D. Role of fibrinogen in cerebrovascular dysfunction after traumatic brain injury. Brain Inj. 2013, 27, 1508-1515. [CrossRef] [PubMed]

172. Schnüriger, B.; Inaba, K.; Abdelsayed, G.A.; Lustenberger, T.; Eberle, B.M.; Barmparas, G.; Talving, P.; Demetriades, D. The impact of platelets on the progression of traumatic intracranial hemorrhage. J. Trauma Acute Care Surg. 2010, 68, 881-885. [CrossRef] [PubMed]

173. Watson, V.L.; Louis, N.; Seminara, B.V.; Muizelaar, J.P.; Alberico, A. Proposal for the rapid reversal of coagulopathy in patients with nonoperative head injuries on anticoagulants and/or antiplatelet agents: A case study and literature review. Neurosurgery 2017, 81, 899-909. [CrossRef] [PubMed]

174. Fiaschi, P.; Iaccarino, C.; Stefini, R.; Prior, E.; Prior, A.; Zona, G. Clinical practice for antiplatelet and anticoagulant therapy in neurosurgery: Data from an Italian survey and summary of current recommendations-part I, antiplatelet therapy. Neurosurg. Rev. 2020, 44, 485-493. [CrossRef] 
175. Keyes, M.; Alley, A.; Muertos, K.; Anderson, B.; Howerton, S.; Burns, A.; Pepe, A. The “Headstrike” Protocol: A Retrospective Review of a Single Trauma Center's Operational Change in the Management of Anticoagulated Ground-Level Falls. Am. Surg. 2019, 85, 821-829. [CrossRef] [PubMed]

176. Godier, A.; Albaladejo, P.; On Perioperative Haemostasis Gihp Group, T. Management of Bleeding Events Associated with Antiplatelet Therapy: Evidence, Uncertainties and Pitfalls. J. Clin. Med. 2020, 9, 2318. [CrossRef] [PubMed]

177. Naidech, A.M.; Liebling, S.M.; Rosenberg, N.F.; Lindholm, P.F.; Bernstein, R.A.; Batjer, H.H.; Alberts, M.J.; Kwaan, H.C. Early platelet transfusion improves platelet activity and may improve outcomes after intracerebral hemorrhage. Neurocrit. Care 2012, 16, 82-87. [CrossRef] [PubMed]

178. Fortuna, G.R.; Mueller, E.W.; James, L.E.; Shutter, L.A.; Butler, K.L. The impact of preinjury antiplatelet and anticoagulant pharmacotherapy on outcomes in elderly patients with hemorrhagic brain injury. Surgery 2008, 144, 598-603, discussion 603-595. [CrossRef]

179. Washington, C.W.; Schuerer, D.J.; Grubb Jr, R.L. Platelet transfusion: An unnecessary risk for mild traumatic brain injury patients on antiplatelet therapy. J. Trauma Acute Care Surg. 2011, 71, 358-363. [CrossRef]

180. Vargas, A.; Bleck, T.P. Hematological Challenges in Intensive Care Unit Patients with Neurological Disease. In Hematologic Challenges in the Critically Ill; Shander, A., Corwin, H.L., Eds.; Springer International Publishing: Cham, Switzerland, 2018; pp. 185-197.

181. Kapapa, T.; Röhrer, S.; Struve, S.; Petscher, M.; König, R.; Wirtz, C.R.; Woischneck, D. Desmopressin acetate in intracranial haemorrhage. Neurol. Res. Int. 2014, 2014, 298767. [CrossRef]

182. Naidech, A.M.; Maas, M.B.; Levasseur-Franklin, K.E.; Liotta, E.M.; Guth, J.C.; Berman, M.; Rosenow, J.M.; Lindholm, P.F.; Bendok, B.R.; Prabhakaran, S. Desmopressin improves platelet activity in acute intracerebral hemorrhage. Stroke 2014, 45, 2451-2453. [CrossRef] [PubMed]

183. Wutzler, S.; Maegele, M.; Marzi, I.; Spanholtz, T.; Wafaisade, A.; Lefering, R.; Trauma Registry of the German Society for Trauma Surgery. Association of preexisting medical conditions with in-hospital mortality in multiple-trauma patients. J. Am. Coll. Surg. 2009, 209, 75-81. [CrossRef]

184. Batchelor, J.S.; Grayson, A. A meta-analysis to determine the effect of anticoagulation on mortality in patients with blunt head trauma. Br. J. Neurosurg. 2012, 26, 525-530. [CrossRef] [PubMed]

185. Fabbri, A.; Servadei, F.; Marchesini, G.; Bronzoni, C.; Montesi, D.; Arietta, L. Antiplatelet therapy and the outcome of subjects with intracranial injury: The Italian SIMEU study. Crit. Care 2013, 17, R53. [CrossRef] [PubMed]

186. Grandhi, R.; Harrison, G.; Voronovich, Z.; Bauer, J.; Chen, S.H.; Nicholas, D.; Alarcon, L.H.; Okonkwo, D.O. Preinjury warfarin, but not antiplatelet medications, increases mortality in elderly traumatic brain injury patients. J. Trauma Acute Care Surg. 2015, 78, 614-621. [CrossRef] [PubMed]

187. Prinz, V.; Finger, T.; Bayerl, S.; Rosenthal, C.; Wolf, S.; Liman, T.; Vajkoczy, P. High prevalence of pharmacologically induced platelet dysfunction in the acute setting of brain injury. Acta Neurochir. 2016, 158, 117-123. [CrossRef] [PubMed]

188. Batchelor, J.S.; Grayson, A. A meta-analysis to determine the effect on survival of platelet transfusions in patients with either spontaneous or traumatic antiplatelet medication-associated intracranial haemorrhage. BMJ Open 2012, 2, e000588. [CrossRef] [PubMed]

189. Batchelor, J.S.; Grayson, A. A meta-analysis to determine the effect of preinjury antiplatelet agents on mortality in patients with blunt head trauma. Br. J. Neurosurg. 2013, 27, 12-18. [CrossRef]

190. Tauber, M.; Koller, H.; Moroder, P.; Hitzl, W.; Resch, H. Secondary intracranial hemorrhage after mild head injury in patients with low-dose acetylsalicylate acid prophylaxis. J. Trauma Acute Care Surg. 2009, 67, 521-525. [CrossRef] [PubMed]

191. Nishijima, D.K.; Shahlaie, K.; Sarkar, K.; Rudisill, N.; Holmes, J.F. Risk of unfavorable long-term outcome in older adults with traumatic intracranial hemorrhage and anticoagulant or antiplatelet use. Am. J. Emerg. Med. 2013, 31, 1244-1247. [CrossRef] [PubMed]

192. Nishijima, D.K.; Offerman, S.R.; Ballard, D.W.; Vinson, D.R.; Chettipally, U.K.; Rauchwerger, A.S.; Reed, M.E.; Holmes, J.F.; Services, C.R.i.E.; Network, T. Risk of traumatic intracranial hemorrhage in patients with head injury and preinjury warfarin or clopidogrel use. Acad. Emerg. Med. 2013, 20, 140-145. [CrossRef]

193. Joseph, B.; Pandit, V.; Aziz, H.; Kulvatunyou, N.; Hashmi, A.; Tang, A.; O’Keeffe, T.; Wynne, J.; Vercruysse, G.; Friese, R.S. Clinical outcomes in traumatic brain injury patients on preinjury clopidogrel: A prospective analysis. J. Trauma Acute Care Surg. 2014, 76, 817-820. [CrossRef] [PubMed]

194. Miller, M.P.; Trujillo, T.C.; Nordenholz, K.E. Practical considerations in emergency management of bleeding in the setting of target-specific oral anticoagulants. Am. J. Emerg. Med. 2014, 32, 375-382. [CrossRef]

195. Feeney, J.M.; Santone, E.; DiFiori, M.; Kis, L.; Jayaraman, V.; Montgomery, S.C. Compared to warfarin, direct oral anticoagulants are associated with lower mortality in patients with blunt traumatic intracranial hemorrhage: A TQIP study. J. Trauma Acute Care Surg. 2016, 81, 843-848. [CrossRef]

196. Maegele, M.; Grottke, O.; Schöchl, H.; Sakowitz, O.; Spannagl, M.; Koscielny, J. Direct Oral Anticoagulants in Emergency Trauma Admissions: Perioperative Management, and Handling Hemorrhage. Dtsch. Ärzteblatt Int. 2016, 113, 575.

197. Hackam, D.G.; Mrkobrada, M. Selective serotonin reuptake inhibitors and brain hemorrhage: A meta-analysis. Neurology 2012, 79, 1862-1865. [CrossRef] 
198. Oberladstätter, D.; Schlimp, C.J.; Zipperle, J.; Osuchowski, M.F.; Voelckel, W.; Grottke, O.; Schöchl, H. Impact of Idarucizumab and Andexanet Alfa on DOAC Plasma Concentration and ClotPro $\left({ }^{\circledR}\right)$ Clotting Time: An Ex Vivo Spiking Study in A Cohort of Trauma Patients. J. Clin. Med. 2021, 10, 3476. [CrossRef] [PubMed]

199. McCully, S.P.; Schreiber, M.A. Traumatic brain injury and its effect on coagulopathy. Semin. Thromb. Hemost. $2013,39,896-901$.

200. Lawrie, R. Coagulopathy in severe, isolated traumatic brain injury: A prevalence study. Master's Thesis, University of Cape Town, Cape Town, South Africa, 2018.

201. Bugaev, N.; Como, J.J.; Golani, G.; Freeman, J.J.; Sawhney, J.S.; Vatsaas, C.J.; Yorkgitis, B.K.; Kreiner, L.A.; Garcia, N.M.; Aziz, H.A. Thromboelastography and Rotational Thromboelastometry in Bleeding Patients with Coagulopathy: Practice Management Guideline from the Eastern Association for the Surgery of Trauma. J. Trauma Acute Care Surg. 2020, 89, 999-1017. [CrossRef] [PubMed]

202. Walsh, M.; Thomas, S.; Kwaan, H.; Aversa, J.; Anderson, S.; Sundararajan, R.; Zimmer, D.; Bunch, C.; Stillson, J.; Draxler, D. Modern methods for monitoring hemorrhagic resuscitation in the United States: Why the delay? J. Trauma Acute Care Surg. 2020, 89, 1018-1022. [CrossRef]

203. Walsh, M.M.; Khan, R.; Kwaan, H.C.; Neal, M.D. Fibrinolysis Shutdown in COVID-19-Associated Coagulopathy: A Crosstalk among Immunity, Coagulation, and Specialists in Medicine and Surgery. J. Am. Coll. Surg. 2021, 232, 1003-1006. [CrossRef] [PubMed]

204. Subramanian, M.; Kaplan, L.J.; Cannon, J.W. Thromboelastography-Guided Resuscitation of the Trauma Patient. JAMA Surg. 2019, 154, 1152-1153. [CrossRef] [PubMed]

205. Moore, E.E.; Thomas, S.G.; Mjaess, N.; Bunch, C.M.; Walsh, M.M. Guiding Hemorrhagic Resuscitation With Viscoelastic Tests in the Emergency Department: A Call to Action in Emergency Medicine Education. Ann. Emerg. Med. 2021, 78, 462-463. [CrossRef] [PubMed]

206. Maegele, M. Coagulopathy and Progression of Intracranial Hemorrhage in Traumatic Brain Injury: Mechanisms, Impact, and Therapeutic Considerations. Neurosurgery 2021, 162, 329-336. 